\title{
Endogenous modulators in the regulation of ion transporting enzymes: structure, function, interactions, recent advancements and future perspectives
}

\author{
Parimal C. Sen
}

Division of Molecular Medicine, Bose Institute, Kolkata, India. Email: parimalsen.boseinst@gmail.com; senpc03@yahoo.com

Received 23 August 2011; revised 29 September 2011; accepted 6 October 2011.

\begin{abstract}
A prerequisite for life is the ability to uphold electrochemical imbalance across biomembranes. Ion transporting enzymes, known as specific pumps, are responsible for the transport of various ions across cell membranes to sustain the same. In all eukaryotes, the plasma membrane potential and secondary transport systems are maintained by the activity of P-type ion transporting enzymes, commonly known as ATPase membrane pumps. Malfunction of pumps leads to various cell disorders and subsequently diseases like cardiac problems, renal malfunctionings, diabetes, cataract, even cancer. Activities/functions of these pumps are regulated either by exogenous agents or by endogenous substances like proteins, peptides, hormones, etc., which are collectively known as modulators. Some of these endogenous modulators may be useful for developing drugs depending on the nature of regulation. For more than last two decades, researchers across the globe are exploring the mechanism of action of different endogenous modulators on these ion transporting enzymes with the aim of developing target-specific drugs. In this review, we have discussed recent advances in our understanding of ATPase pumps, e.g., $\mathrm{Ca}^{2+}-, \mathrm{Na}^{+}, \mathrm{K}^{+}-, \mathrm{Ca}^{2+}, \mathrm{Mg}^{2+}$, $\mathrm{H}^{+}, \mathrm{K}^{+}$-ATPases, with the emphasis on their functional regulation by a number of endogenous modulators, and the implications of development of some of these modulators as potential drugs.
\end{abstract}

Keywords: ATPases; Endogenous Protein/Peptides; FXYD; Phospholamban; Sarcolipin; Interleukin; Regulations

\section{INTRODUCTION}

Transport enzymes are those responsible for the tran- sport of ions across the cell membranes. The transport takes place against ion gradient, energy required for the process is provided by ATP, which is hydrolyzed to ADP and $\mathrm{Pi}$ during these transport phenomena. These are a large group of evolutionary conserved ion pumps that are found in bacteria, archaea and higher eukaryotes and belong to P-type ATPases (includes $\mathrm{Na}^{+}, \mathrm{K}^{+}, \mathrm{Ca}^{2+}, \mathrm{H}^{+}$, $\mathrm{K}^{+}$-ATPases) and are involved in performing different fundamental processes in biology and medicine, ranging from the generation of membrane potential to muscle contraction, the removal of toxic ions from cells, maintaining proper acidity inside cells etc. [1]. Mutation or dysfunction of these ATPases leads to several diseases. Malfunction of $\mathrm{Ca}^{2+}$-ATPase may lead to defect in cardiac function, infertility, diabetes and even cancer [2]. Impairment of sodium pumps, on the other hand, cause diseases including osteoporosis, hypertension, familiar hemiplegic migraine. P-type ATPases, that transport monovalent and divalent cations such as $\mathrm{Na}^{+}, \mathrm{K}^{+}, \mathrm{Ca}^{2+}, \mathrm{Cu}^{+}$, $\mathrm{Ag}^{+}, \mathrm{Zn}^{2+}, \mathrm{Cd}^{2+}, \mathrm{Ni}^{2+}$ etc., are divided into five subfamilies on the basis of the conserved sequences [3].

It is now well established that all these P-type ATPases are regulated by endogenous modualtors like, peptides, proteins and other small molecules.

\section{1. $\mathrm{Na}^{+}, \mathrm{K}^{+}$-ATPase}

The $\mathrm{Na}^{+}, \mathrm{K}^{+}$-ATPase commonly known as sodium pump, is responsible for coupled extrusion and uptake of $\mathrm{Na}^{+}$and $\mathrm{K}^{+}$ions across the plasma membranes of most eukaryotic organisms. $\mathrm{Na}^{+}, \mathrm{K}^{+}$-ATPase is a member of the $\mathrm{P}_{2 \mathrm{c}}$ family of P-type ATPases superfamily [4]. The pump drives three sodium ions out of the cell and two potassium ions into the cell against substantial concentration gradient. The activity of this enzyme is required for diverse functions like maintenance of cellular osmotic balance, generation of neuronal membrane potentials and renal as well as intestinal handling of solutes. This is a $(\alpha / \beta)_{2}$ dimeric integral membrane 
protein and is composed of a $100-\mathrm{kDa} \alpha$-subunit and a heavily glycosylated $\beta$-subunit of molecular weight about $55 \mathrm{kDa}$ [5]. In addition, $\mathrm{Na}^{+}, \mathrm{K}^{+}$-ATPase is associated with a third subunit belonging to the FXYD protein family [6]. Isoforms exist for both the $\alpha\left(\alpha_{1}, \alpha_{2}, \alpha_{3}\right)$ and $\beta\left(\beta_{1}, \beta_{2}, \beta_{3}\right)$ subunits. These isoforms are expressed variedly in different mammalian tissues [7-10] with various $\alpha \beta$ combinations. The $\mathrm{Na}^{+}, \mathrm{K}^{+}$-ATPase can function as an $\alpha \beta$ protomer, but it is postulated that the $\mathrm{Na}^{+}, \mathrm{K}^{+}$-ATPase is composed of $(\alpha / \beta)_{2}$ dimer in vivo. $\alpha$ subunit contains ATP binding site, phosphorylation site, and amino acids essential for the binding of cations and cardiac glycosides which suggests that this subunit plays a major role in the catalytic function of the enzyme. The $\beta$ subunit appears to be involved in maturation of the enzyme, localization of ATPase to the plasma membrane, and stabilization of a $\mathrm{K}^{+}$-bound intermediate form of the protein [11]. The other low molecular mass transmembrane proteins were named after the invariant extracellular motif FXYD [6]. One central role of the FXYD proteins is to interact with the $\mathrm{Na}^{+}$, $\mathrm{K}^{+}$-ATPase and modulate its properties. There are seven FXYD proteins. Because each of these proteins has a different tissue distribution and functional effects, the current hypothesis is that FXYD proteins act as tissue-specific modulators of $\mathrm{Na}^{+}, \mathrm{K}^{+}$-ATPase that adjust or fine-tune its kinetic properties to the specific needs of a given tissue, cell type, or physiological state, without affecting it elsewhere $[12,13]$.

\section{2. $\mathrm{Ca}^{2+}$-ATPase}

$\mathrm{Ca}^{2+}$-ATPase or the $\mathrm{Ca}^{2+}$-pump on the other hand is responsible for the transport of $\mathrm{Ca}^{2+}$ across cell membranes and thus maintains intracellular calcium concentration. Because of its peculiar flexibility as a ligand, calcium regulates all important aspects of cellular activeity, beginning with the creation of new life at fertilization and ending with the dramatic event of apoptotic suicide at the end of the life cycle. $\mathrm{Ca}^{2+}$ may also function as a bonafide first messenger since it interacts with the exterior of cellular membrane as if it were a hormone or growth factor [14]. $\mathrm{Ca}^{2+}$ is distinctly ambivalent molecule that is essential for life. Cells have an absolute dependence on the messenger function of $\mathrm{Ca}^{2+}$. In order to function properly, its homeostasis must be controlled with absolute precision, failing of which, there can be a sustained cellular $\mathrm{Ca}^{2+}$ overload leading to apoptotic and/or necrotic cell death [15]. The cytoplasmic free $\mathrm{Ca}^{2+}$ concentration in all cell types at rest is very low $(50 \mathrm{nM}-150 \mathrm{nM})$ which is $10^{3}-10^{4}$ times lower than the free $\mathrm{Ca}^{2+}$ concentration in the extracellular space (usually $1 \mathrm{mM}$ ) or in the lumen of sarco(endo)plasmic reticulum (SR/ER) $(0.1 \mathrm{mM}-2.0$
$\mathrm{mM}$ ). Such large $\mathrm{Ca}^{2+}$ gradients across cellular boundaries are established and maintained by the powerful calcium pumps located in the plasma membranes and in sarco (endo) plasmic reticulum [16] with contributions from other cellular organelles.

The $\mathrm{Ca}^{2+}$ transporting systems can be classified into four basic transporting modes i.e. ATPases, exchangers, channels and uniporters. In general, whenever the situation demands the fine regulation of $\mathrm{Ca}^{2+}$ in submicromolar concentrations, the ATPase mode are chosen, since this appears to be the only transport system with the ability to interact with high $\mathrm{Ca}^{2+}$ affinity and is therefore used by plasma membrane and sarcoendoplasmic reticulum.

The ATP dependent $\mathrm{Ca}^{2+}$ pumps of sarco (endo) plasmic reticulm (SERCA) constitute a large family of proteins of $100 \mathrm{kDa}-138 \mathrm{kDa}$ [17-21] and a proteolipid of molecular mass $6 \mathrm{kDa}-12 \mathrm{kDa}[22]$, belonging to $\mathrm{P}_{2}$ subfamily (subtype 2A) of P-type ATPases. They are structurally distinct from the $\mathrm{Ca}^{2+}$ pump of the plasma membrane, but share similarities in the mechanism of calcium translocation. The intracellular location of SERCA exclusively in SR/ER membranes is maintained by the presence of specific retention/retrieval motifs in their primary sequences. The $\mathrm{Ca}^{2+}$ transport is reversible and under favourable condition results in the formation of ATP molecule for two $\mathrm{Ca}^{2+}$ ions released from the lumen of SR [23]. Counter-transport of $\mathrm{H}^{+}$and fluxes of ions through the anion and cation channels of SR prevent large changes in membrane potential during $\mathrm{Ca}^{2+}$ transport. The SERCA pumps have high affinity for $\mathrm{Ca}^{2+}\left(\mathrm{K}_{\mathrm{m}}\right.$ about $0.1 \mu \mathrm{M}$ ), and are capable of maintaining a resting cytoplasmic $\left[\mathrm{Ca}^{2+}\right]$ of $10 \mathrm{nM}-20 \mathrm{nM}$.

The plasma membrane $\mathrm{Ca}^{2+}$-ATPase (PMCA) is the only high affinity $\mathrm{Ca}^{2+}$ transporting system present in the plasma membrane and belongs to the $\mathrm{P}_{2}$ (subtype $2 \mathrm{~B}$ ) subfamily of P-type ATPases [24]. The molecular mass is $130 \mathrm{kDa}-140 \mathrm{kDa}$ and are characterized by the formation of an aspartyl phosphate intermediate as part of their reaction cycle [25]. At variance with the closely allied SERCA, PMCA contains only one $\mathrm{Ca}^{2+}$ binding site, and indeed transports one $\mathrm{Ca}^{2+}$ as one ATP molecule is hydrolyzed.

In addition to $\mathrm{Mg}^{2+}$-dependent $\mathrm{Ca}^{2+}$-ATPase, another $\mathrm{Ca}^{2+}$-ATPase which can be activated without any $\mathrm{Mg}^{2+}$ has also been reported from a number of tissues and sources with varying sensitivity to calcium and insensitivity to magnesium [26-34]. Both these ATPases are having similar properties [35-37]. They may either be the two forms of the same enzyme having separate catalytic sites or same catalytic site with different sensitivities to $\mathrm{Mg}^{2+}[36,38,39]$. 


\section{3. $\mathrm{H}^{+}, \mathrm{K}^{+}$-ATPase}

The gastric $\mathrm{H}^{+}, \mathrm{K}^{+}$-ATPase is an alpha beta $(\alpha \beta)$ heterodimeric member of the eukaryotic alkali-cation P2type ion-motive ATPase family which undergoes a cycle of phosphorylation and dephosphorylation coupled to the outward and inward transport of hydrogen and potassium ions, respectively. The secretory canaliculus of the parietal cell present in the gastric glands of the stomach perform secretion of hydrochloric acid upon hormonal stimulation [40-43]. The ATPase sustains a 10-fold inward potassium gradient $\left(150 \mathrm{mM} \mathrm{K}^{+}\right.$in, $15 \mathrm{mM} \mathrm{K}^{+}$out $)$ and a transmembrane outward hydrogen ion gradient of greater than 1 million fold to generate a luminal $\mathrm{pH}$ of 0.8 . This is the largest ion gradient generated by a P2 type ATPase.

The molecular weight of $\alpha$ subunit is $\sim 114 \mathrm{kDa}$ and that of the glycosylated $\beta$ subunit is $\sim 65 \mathrm{kDa}$. The $\alpha$ subunit of hog, rat and sheep is predicted to span the membrane 10 times and a $\beta$ subunit only once [40,41]. The primary structure of the $\alpha$ subunit of gastric $\mathrm{H}^{+}, \mathrm{K}^{+}$ -ATPase ( $\left.\mathrm{HK} \alpha_{1}\right)$ shows significant homology to the $\mathrm{Na}^{+}$, $\mathrm{K}^{+}$-ATPase $(62 \%)$ and SR $\mathrm{Ca}^{2+}$-ATPase $(29 \%)$ while the $\beta$ subunits of $\mathrm{H}^{+}, \mathrm{K}^{+}$-ATPase and $\mathrm{Na}^{+}, \mathrm{K}^{+}$-ATPase are $35 \%$ identical [41].

All these above mentioned ATPases have been reported to be regulated by endogenous proteins, peptides, hormones and/or other small molecules to different extent [44,45], collectively known as 'modulators'. For more than two decades scientists across the globe have been exploring different aspects of the regulation of these ion transporting enzymes by endogenous modultors.

In the present review, structure-functions of different ATPases, how they are regulated by endogenous modulators like peptides, proteins and other compounds, as well as the mechanism of their regulation and the implications/importance have been described.

\section{STRUCTURE AND FUNCTION OF ATPASES}

Jens Skou in 1957 first examined the effect of different cations, e.g. $\mathrm{Na}^{+}$and $\mathrm{K}^{+}$(later named as $\mathrm{Na}^{+}, \mathrm{K}^{+}$-ATPase) [46] in leg nerve homogenates of crabs. He was finally awarded the Nobel Prize in Chemistry in 2001, i.e., 40 years after the discovery. It is specifically and characteristically identified in its inhibition by extra cellular binding of cardiac glycosides, the most widely used and well known one is ouabain [47].

Subsequent to his discovery in 1961, other ion pumps, like $\mathrm{Ca}^{2+}$-pump [48] with comparable characteristics but different properties were identified from different tissues and organisms. Most important and well characterized of them are sarcoplasmic-reticulm (SR) $\mathrm{Ca}^{2+}$-ATPase, which controls the contraction of skeletal muscl [17].

$\mathrm{H}^{+}, \mathrm{K}^{+}$-ATPase, another ion transporting enzyme mainly present in the gastric cells, is well known for its vigorous role during acid secretion process. It is homologous in sequence to the $\mathrm{Na}^{+}, \mathrm{K}^{+}$-ATPase and the $\mathrm{Ca}^{2+}$-ATPase and has a similar pattern of transmembrane helices.

The biochemical properties that are common among these ATPases are: 1) formation of an acid-stable, phosphorylated aspartic acid residue during the pumping cycle (that is phosphorylated intermediate) and 2) inhibition by orthovanadate.

The mechanism of the $\mathrm{Ca}^{2+}$ ATPase is usually discussed in terms of the $E_{1}-E_{2}$ model developed from the Post-Albers scheme for $\mathrm{Na}^{+}, \mathrm{K}^{+}$-ATPase [49]. All these ATPases follow a similar catalytic cycle as described by Post-Albers [49] for $\mathrm{Na}^{+}, \mathrm{K}^{+}$-ATPase. The reaction cycle of the $\mathrm{Ca}^{2+}$ ATPase is shown in Figure 1.

Either ATP or $\mathrm{Ca}^{+2}$ can bind first to the $\mathrm{E}_{1}$ conformation of the $\mathrm{Ca}^{2+}$-ATPase. A series of conformational changes lead to the intermediate $\mathrm{E}_{1}$ " $\mathrm{Ca}_{2}$. ATP, which undergoes phosphorylation to give $\mathrm{E}_{2} \mathrm{PCa}_{2}$. This leads to the release of $\mathrm{Ca}^{2+}$ into the lumen followed by dephosphorylation to form $E_{2}$, which then returns to $E_{1}$.

The above model proposes that $\mathrm{Ca}^{2+}$-ATPase (SERCA) can exist in one of the two distinct forms, $\mathrm{E}_{1}$ or $\mathrm{E}_{2}$. In the $\mathrm{E}_{1}$ conformation, the ATPase can bind two $\mathrm{Ca}^{2+}$ ions from the cytoplasmic site of the membrane with high affinity whereas in the $E_{2}$ conformation these two sites are closed. Following binding of ATP, the enzyme is phosphorylated on Asp-351 to give a phosphorylated intermediate $\mathrm{E}_{2} \mathrm{PCa}_{2}$, a state in which two $\mathrm{Ca}^{2+}$ binding sites are of low affinity and face inwards, the lumen of the SR. Following the loss of $\mathrm{Ca}^{2+}$ to the lumen of the $\mathrm{SR}$, the ATPase dephosphorylates to $\mathrm{E}_{2}$ and then recycles to $E_{1}$. The phosphorylation events on the $\mathrm{Ca}^{2+}$-ATPase are reversible.

Putative structure of the plasma membrane $\mathrm{Ca}^{2+}$-ATPase indicating the key functional sites are shown in Figure 1.

Putative structure of the plasma membrane $\mathrm{Ca}^{2+}$-ATPase indicating the key functional sites [50] are shown in Figure 2.

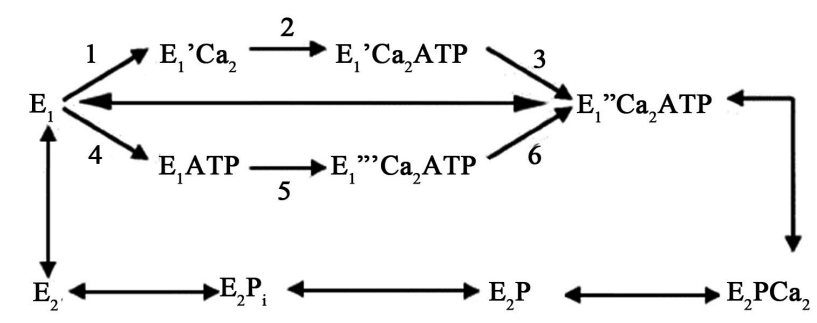

Figure 1. $\mathrm{E}_{1} / \mathrm{E}_{2}$ scheme for $\mathrm{Ca}^{2+}$-ATPase. 


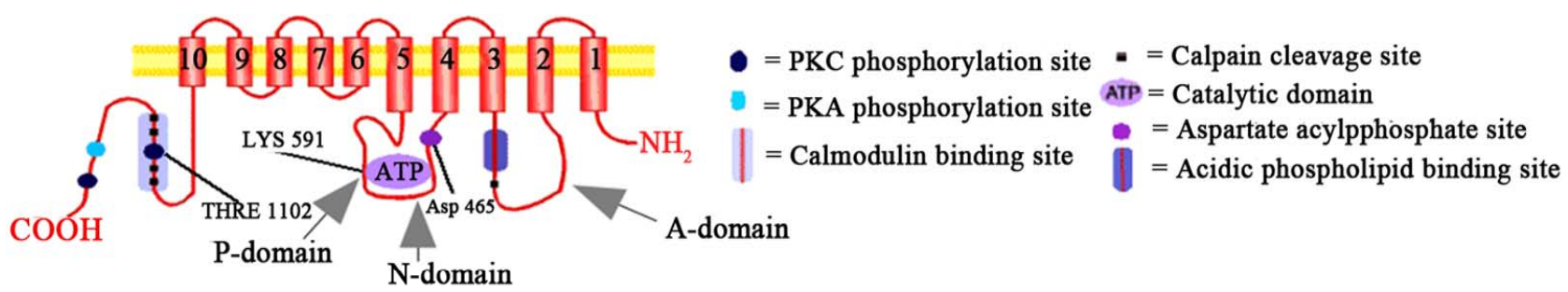

Figure 2. Putative structure of the plasma membrane $\mathrm{Ca}^{2+}$-ATPase indicating the key functional sites [50].

In the plasma membrane, the enzyme is organized with ten transmembrane domains, and the $\mathrm{NH}_{2}$ and $\mathrm{COOH}$ termini are both located on the cytosolic side of the membrane. The bulk of the protein mass is facing the cytosol and consists of three major parts: the intracellular loop between transmembrane segments 2 and 3, the large unit between membrane-spanning domains 4 and 5, and the extended "tail" following the last transmembrane domain [51,52]. The first intracellular loop region between membrane-spanning domains 2 and 3 corresponds to the "transduction domain" is believed to play an important role in the long-range transmission of conformational changes occurring during the transport cycle. The large cytosolic region of $\sim 400$ residues between membrane spanning segments 4 and 5 contains the major catalytic domain including the ATP binding site and the invariate aspartate residue that forms the acyl phosphate intermediate during ATP hydrolysis. Finally, the extended $\mathrm{COOH}$-terminal tail corresponds to the major regulatory domain (calmodulin-binding domain) of the PMCAs [53,54].

The PMCAs closely resemble that of the SERCA [sister pump of sarco (endo) plasmic reticulum] [55]. Indeed, the major global difference between the two types of calcium pumps is confined to the C-terminal tail, which is generally much smaller in the SERCAs (ranging from $<20$ to $\sim 50$ residues) than in the PMCAs (70 to 200 residues). Unlike SERCA pump, it only contains one $\mathrm{Ca}^{2+}$-binding site, and indeed transports one $\mathrm{Ca}^{2+}$ as one ATP molecule is hydrolyzed.

All P-type ATPases have an architectural commonality, with cytoplasmic domains which are linked to a transmembrane module. The three cytoplasmic domains [known as the phosphorylation $(\mathrm{P})$, nucleotide binding $(\mathrm{N})$ and actuator (A) domains], as revealed from the first high resolution X-ray structure of the sarco (endo) plasmatic reticulum $\mathrm{Ca}^{2+}$-ATPase (SERCA) which exchanges $\mathrm{Ca}^{2+}$ for protons) [17] are responsible for ATP hydrolysis. The P-type ATPases have six transmembrane helices (M1 - M6) that make up the core of the membrane transport domains. Both these subclasses have ten trans-membrane helices (M1 - M10): the core segment (M1 - M6) and an additional carboxyterminal transmembrane segment (M7 - M10). Many P-type ATPases also have regulatory $(\mathrm{R})$ domains, which typically inhibit their function [24]. Crystallographic studies have provided detail information on the pumping mechanism of rabbit SERCA1a [17-19,56-58].

The functional cycle of P-type ATPases is typically denoted by $E_{1}$ and $E_{2}$ states which in case of SERCA relate to the binding and active transport of cytoplasmic $\mathrm{Ca}^{2+}$ and the countertransport of luminal $\mathrm{H}^{+}$to the cytoplasm, respectively. In $\mathrm{Ca}^{2+}$ translocation, ATP is involved as the key substrate in the formation of the $\mathrm{Ca}^{2+}$ occluded $\mathrm{E}_{1}-\mathrm{P}$ state [56]. However, ATP at physio-logical concentrations also exhibits a general, stimulatory effect on the functional cycle of SERCA relating to a noncatalytic, modulatory mode of binding to the various ATPase intermediates. A key question as to the mechanism of SERCA is then to address the structural and functional properties of the modulatory ATP binding site in comparison to the catalytic site and to make possible extrapolations to other P-type ATPases [59].

There is evidence from mutational studies [60,61], and X-ray crystallography [19,56] which strongly suggests for a direct involvement of the conserved residues in the $\mathrm{N}$-domain in nucleotide binding region of rabbit SERCA1a. Another puzzling observation relates to the structure of SERCA in the $\mathrm{Ca}_{2} \mathrm{E}_{1}$ state, which exhibits an open conformation with the $\mathrm{N}$ - and A-domains detached from the P-domain [17].

The complete structural shape of the $\mathrm{Na}^{+}, \mathrm{K}^{+}$-ATPase and identification of the individual domains based on a docking model derived from SERCA1a have been reported [62]. Recently, new information on the structure and function of the $\mathrm{Na}^{+}, \mathrm{K}^{+}$-ATPase and the $\mathrm{H}^{+}$-ATPase has emerged from $\mathrm{X}$-ray crystal structures of the autoinhibited plasma membrane $\mathrm{H}^{+}$-ATPase from Arabidopsis thaliana (AHA2) [63] and of the pig renal $\alpha_{1} \beta_{1} \gamma \mathrm{Na}^{+}$, $\mathrm{K}^{+}$-ATPase complex (pNKA) $[64,65]$. A structure of shark $\mathrm{Na}^{+}, \mathrm{K}^{+}$-ATPase (sNKA) was determined at $2.4 \mathrm{~A}$ resolution [66] and was found to be similar to that of pNKA. This structure more accurately resolved the atomic interactions within the $\mathrm{Na}^{+}, \mathrm{K}^{+}$-ATPase, completed the $\beta$ subunit ectodomain structure cholesterol $[64,65]$. The mechanism by which P-type ATPases function and how it is coupled to ATP hydrolysis, general and specific transport mechanisms have been proposed on 
the basis of protein chemistry and mutagenesis experiments using various P-type ATPases [15,67-71] together with structural studies of the $\mathrm{Ca}^{2+}$-ATPase from rabbit SERCA [19,69,72,73].

When the transported cations (three $\mathrm{Na}^{+}$for the $\mathrm{Na}^{+}$, $\mathrm{K}^{+}$-ATPase; one proton for $\mathrm{H}^{+}$-ATPases) are bound at the membrane transport domain of the ATPase, a conformational change occurs and transmits to the $\mathrm{P}$ domain, predominantly by the M4 helix $[17,18,58,59,74]$. Conformational changes associated with the functional cycle can be examined from studying the $\mathrm{Ca}^{2+}$-ATPase. The bound cations are occluded in the $\mathrm{E}_{1} \mathrm{P}$ state. Occlusion occurs during phosphorylation owing to the formation of an ATP mediated cross link of the $\mathrm{N}$ and $\mathrm{P}$ domains, which moves the A domain to the side [19,73]. As the $\mathrm{K}^{+}$ ions of the $\mathrm{Na}^{+}$pump bind (or when the $\mathrm{H}^{+}$-ATPase has formed a proposed intramolecular salt bridge), the induced closure of the $\mathrm{E}_{2} \mathrm{P}$ state stimulates dephosphorylation, and this is mediated by the TGE motif of the A domain which activates a water molecule at the phosphorylation site. Dephosphorylation leads to an occluded $\mathrm{E}_{2}$ state, with two $\mathrm{K}^{+}$ions present in the occlusion cavity of $\mathrm{Na}^{+}, \mathrm{K}^{+}$-ATPase $[19,64,75]$. In the $\mathrm{E}_{2}$ state, ATP is bound at the $\mathrm{N}$ domain and stimulates an $\mathrm{E}_{2}$ to $\mathrm{E}_{1}$ transition by interfering with residues involved in tertiary interactions between domains [59].

For the $\mathrm{Na}^{+}, \mathrm{K}^{+}$-TPase and SERCA, the M7 - M10 segments provide additional coordinating groups fo ions bound at the core region of the $\mathrm{M}$ domain and thus contribute to selectivity $[17,64]$. For $\mathrm{Na}^{+}, \mathrm{K}^{+}$-ATPase, the M7 - M10 helices were shown to have strong influence on the $\mathrm{Na}^{+}$affinity, as determined by the $\alpha$ subunit $\mathrm{C}$ terminus and its interaction network [64,65,76-79]. An overview of the structural aspects of plasma membrane $\mathrm{Na}^{+}, \mathrm{K}^{+}$-ATPase and $\mathrm{H}^{+}$-ATPase ion pumps has been published recently [80].

\section{DIVERSITY IN UNITY IN THE FUNCTION OF ATPASES}

The mechanism of ion coordination and transport of P-type ATPase was first revealed after determination of the molecular structure of the sarcoplasmic reticulum $\mathrm{Ca}^{2+}$-ATPase in an $\mathrm{E}_{1}$ conformation at $2.6 \mathrm{~A}$ resolution [17]. Furthermore, the structure of the $\mathrm{Ca}^{2+}$-ATPase in $\mathrm{E}_{2}$ conformations bound with phosphate analogues has also been identified $[19,57,73,81]$. These structures show that the three cytoplasmic domains rearrange to move six out of ten transmembrane helices, thereby changing the affinity of the $\mathrm{Ca}^{2+}$-binding sites and the gating of the ion pathway. These structural data have allowed construction of homology models that address the central questions of mechanism of active cation transport by all P-type cation pumps. However, for $\mathrm{Na}^{+}, \mathrm{K}^{+}$-ATPase and $\mathrm{H}^{+}, \mathrm{K}^{+}$-ATPase, which consist of both $\alpha$ and $\beta$-subunits, there may be some specific differences in regions of subunit interactions. Mutagenesis, proteolytic cleavage, and transition metal-catalyzed oxidative cleavages have provided evidence about residues involved in binding of $\mathrm{Na}^{+}, \mathrm{K}^{+}$, ATP, and $\mathrm{Mg}^{2+}$ ions and changes accompanying $\mathrm{E}_{1}-\mathrm{E}_{2}$ or $\mathrm{E}_{1}-\mathrm{P}-\mathrm{E}_{2}-\mathrm{P}$ conformational transitions [67]. Recently Ogawa et al. [75] described the crystal structure of $\mathrm{Na}^{+}, \mathrm{K}^{+}$. ATPase with bound ouabain, a representative cardiac glycoside, at 2.8 A resolution in a state analogous to $E_{2}$. $2 \mathrm{~K}^{+}$. Pi. Ouabain is deeply inserted into the transmembrane domain with the lactone ring very close to the bound $\mathrm{K}^{+}$, in marked contrast to previous models. Due to antagonism between ouabain and $\mathrm{K}^{+}$, the structure represents a low-affinity ouabain-bound state. Yet, most of the mutagenesis data obtained with the high-affinity state are readily explained by the present crystal structure, indicating that the binding site for ouabain is essentially the same [75]. The crystal structure also shows that the beta-subunit has a critical role in $\mathrm{K}^{+}$binding and explains, at least partially, why the homologous $\mathrm{Ca}^{2+}$. ATPase counter-transports $\mathrm{H}^{+}$rather than $\mathrm{K}^{+}$, despite the coordinating residues being almost identical [66]. Morth et al. [64] has shown that the beta- and gamma-subunits specific to the $\mathrm{Na}^{+}, \mathrm{K}^{+}$-ATPase are associated with transmembrane helices alpha-M7/alphaM10 and alphaM9, respectively. Electron microscopy has revealed the overall shape of proton pumps. The structure of a P-type proton pump determined by X-ray crystallography shows the ten transmembrane helices and three cytoplasmic domains define the functional unit of ATP-coupled proton transport across the plasma membrane, and the structure is locked in a functional state not previously observed in P-type ATPases [80].

\section{ATPASES AND ENDOGENOUS MODULATORS}

\subsection{Regulation of $\mathrm{Na}^{+}, \mathrm{K}^{+}$-ATPase}

$\mathrm{Na}^{+}, \mathrm{K}^{+}$-ATPase is found to be regulated by the endogenous factors , e.g. peptides, proteins, hormones or other small molecules, known as modulators [45]. There are two types of factors: 1) peptidic and 2) nonpeptidic [82-84]. Physiologically, ATPase actions are controlled by endogenous regulator proteins. It has been reported that an endogenous inhibitor protein inhibits porcine spem motility and a competitive inhibitor of $\mathrm{Na}^{+}, \mathrm{K}^{+}$. ATPase and is identical to $\beta$-microseminoprotein [85]. The regulators of $\mathrm{Na}^{+}, \mathrm{K}^{+}$-ATPase can be divided into two groups: (a) direct modulators e.g., ouabain, some proteins and peptides and (b) indirect modulators which include many peptides, nonpeptideic hormones and neurotransmitters etc. [82,83]. The former group can bind directly with enzyme protein but the latter group of compounds affect via binding to membranes of specific re- 
ceptors. $\mathrm{Na}^{+}, \mathrm{K}^{+}$-ATPase is also inhibited by some endogenous glycosides [86], insulin [87], aldosterone [88], endothelin-1 (ET-1) [89], thyroxin [90], bradykinin [91] and the N-terminal fragment of substance P (SPI-5) [92] most likely via receptor-mediated mechanism.

A group of proteins known as FXYD proteins, a family of seven homologous single transmem-brane segment proteins (FXYD1-7), has been observed to be expressed in a tissue-specific fashion and regulate $\mathrm{Na}^{+}, \mathrm{K}^{+}$-ATPase activity. Most of them are short chain single proteins ( $>$ 100 amino acids) except FXYD5 which is an atypically long N-terminal sequence [44]. It has been suggested that seven members of this family, FXYD1 (phospholemman) [93], FXYD2 ( $\gamma$-subunit of $\mathrm{Na}^{+}, \mathrm{K}^{+}$-ATPase) [94,95], FXYD3 (Mat-8) [96], FXYD4 (CHIF) [97,98], FXYD5 (RIC, dysadherin) [99], FXYD6 (Phosphohippolin) (7) and FXYD7 [100], are auxiliary subunits of $\mathrm{Na}^{+}, \mathrm{K}^{+}$-ATPase. FXYD6 is unique in its expression in the inner ear, suggesting a role in endolymph compostion [101]. Another FXYD protein called FXYD10 with 74 amino acids has been reported to regulate the activity of shark $\mathrm{Na}^{+}, \mathrm{K}^{+}$-ATPase [102]. Some endogenous peptides of varying molecular weights regulate $\mathrm{Na}^{+}, \mathrm{K}^{+}$ATPase [103,104]. Recent work of our laboratory has suggested that endogenous proteins of varying molecular masses isolated from different sources can either inhibit or stimulate ATPase activities [37,105-107]. The inhibittors were found to inhibit partly the $\mathrm{H}^{+}, \mathrm{K}^{+}$-ATPase also. The findings suggested that these proteins inhibit specifically monovalent ion transporting enzymes. Partial amino acid sequence of the $70 \mathrm{kDa}$ inhibitor protein of $\mathrm{Na}^{+}, \mathrm{K}^{+}$-ATPase from goat spermatozoa cytosol [108] showed about $80 \%$ - 100\% homology with mice [109], pig [110] and human [111] testicular aryl sulphatase. Another novel protein, MONaKA was reported to interact with plasma membrane $\mathrm{Na}^{+}, \mathrm{K}^{+}$-ATPase and modulates its activity [112].

Purification of non-peptidic endogenous $\mathrm{Na}^{+}, \mathrm{K}^{+}$-ATPase inhibitors to its high purity has been reported [113] and the structures of three peptidic inhibitors (SPAI-1, $-2,-3)$ have been revealed [114]. A small peptide of molecular mass approximately 600 dalton isolated from human cerebrospinal fluid has been found to specifically inhibit $\mathrm{Na}^{+}, \mathrm{K}^{+}$-pump [115].

The involvement of cAMP-dependent protein kinase (PKA) in acute sodium pump regulation has been documented in 20 different mammalian tissues and in lower vertebrates [116]. The result can be either stimulation or inhibition of the pump, however, and in no case is the pathway completely understood. These structure of the $\mathrm{Ca}^{2+}$-ATPase loop homologous to the $\mathrm{Na}^{+}, \mathrm{K}^{+}$-ATPase, it was suggested that PKA site should be inaccessible to the kinase [117]. Regulation occurs on several levels: biosynthesis and degradation; reversible recruitment to and internalization from the plasma membrane; alteration of affinity for $\mathrm{Na}^{+}$; and either stimulation or inhibittion of activity.

\subsection{Regulation of $\mathrm{Ca}^{2+}$-ATPase}

Fewer reports are available on endogenous protein stimulators/inhibitors of $\mathrm{Ca}^{2+}$-ATPases. Calmodulin is the naturally occurring activator of plasma membrane $\mathrm{Ca}^{2+}$. ATPase. A protein of molecular weight $63 \mathrm{kDa}$ from human erythrocyte membrane [118], and another 56 $\mathrm{kDa}-60 \mathrm{kDa}$ from dog and beef heart sarcolemma have been reported to stimulate $\mathrm{Mg}^{2+}, \mathrm{Ca}^{2+}$-ATPase. Regucalcin, a calcium binding protein plays a pivotal role in maintaining intracellular $\mathrm{Ca}^{2+}$ homeostasis due to activetion of $\mathrm{Ca}^{2+}$ pump enzymes in plasma membrane (basolateral membrane), microsomes (endoplasmic reticulum) and mitochondria of many cell types [119]. Other activators are acidic phospholipids and long chain polyunsaturated fatty acids [120]. Phosphorylation by protein kinase $\mathrm{A}$ and protein kinase $\mathrm{A}$ inhibitor (PKI) purified from bovine heart stimulates $\mathrm{Ca}^{2+}, \mathrm{Mg}^{2+}$-ATPase activity in human erythrocytes [121]. Recently, PDC-109, the major secretory protein from bull seminal vesicles has been described to stimulate bovine sperm membrane $\mathrm{Ca}^{2+}$-ATPase. An analysis of the enzyme kinetics data suggested irreversible, cooperative interaction of PDC 109 with the enzyme, the stimulation being organ specific, but not species specific [33]. A $12 \mathrm{kDa}$ protein from rat brain cytosol reported from the author's laboratory has been found to inhibit $\mathrm{Mg}^{2+}$-independent $\mathrm{Ca}^{2+}$. ATPase while stimulating the $\mathrm{Mg}^{2+}$-dependent form of the enzyme [37], another $14 \mathrm{kDa}$ protein either from goat spermatozoa $[122,123]$ or bovine brain $[124,125]$ is found to stimulate $\mathrm{Mg}^{2+}$-independent $\mathrm{Ca}^{2+}$-ATPase without any significant effect on $\mathrm{Mg}^{2+}$-dependent form of the ezyme. Narayanan et al. [126] reported a cytosolic protein fraction, termed CPF-I, obtained by $\left(\mathrm{NH}_{4}\right)_{2} \mathrm{SO}_{4}$ fractionation of rabbit heart cytosol which caused marked inhibition (up to 95\%) of ATP-dependent $\mathrm{Ca}^{2+}$ uptake by cardiac sarcoplasm reticulumn. An endogenous inhibitor of SR $\mathrm{Ca}^{+2}$-ATPase has been reported from human placenta, distributed in cytosol and microsomal fractions [127].

Sarcolipin (SLN) in vitro inhibits SERCA1 or SERCA2 pump activity. However the exact nature of regulation by sarcolipin is not fully understood [128]. Phopholamban (PLN), an oligomeric proteolipid has been reported to inhibit cardiac $\mathrm{Ca}^{2+}$-ATPase [129]. It is composed of 52 amino acids and is organized in three domains: (a) cytosolic domain 1a (amino acids 1 - 20); cytosolic domain $1 \mathrm{~b}$ (amino acids 21 - 30) and domain II 
(amino acids 31 - 52) which tranverse the domains [130]. Various attempts have been made to therapeutically target of SERCA2a and PLN in animal and human heart failure models [131]. In vitro mutagenesis studies evaluating the interaction between PLN and SERCA2a have been directed toward the cytoplasmic domains (aa residue, 1 - 30), which include the phosphorylation sites in PLN. These studies demonstrate the importance of PLN interaction with SERCA2a and suggest that interferance with this interaction may provide a novel therapeutic approach for prevention of dilated cardiomyopathy. Convincing evidence suggested that the impaired function of the SR to cycle $\mathrm{Ca}^{2+}$ during diastole and systole is a critical defect in cardiomyocytes from failing hearts. Strategies to interfere with the PLN/SERCA2a interacttion have been proposed as therapy to improve $\mathrm{Ca}^{2+}$ cycling, contractility, and relaxation in failing and nonfailing animal and human heart models [132]. The recent mutation identified in a human genetic study has suggested the need for further refinement of the new therapeutic concept of PLN inhibition [133]. A class of inhibitors has emerged, named "caloxins" defined as substances that bind to the PEDs (putative extracellular domains) in PMCA to inhibit any conformational changes in them during the reaction cycle and hence modulate PMCA activity. The first caloxin (caloxin 2A1) was discovered as a peptide that would bind a synthetic peptide corresponding to the sequence of PED2 of PMCA [134]. Caloxin 2A1 does not affect the activities of $\mathrm{Mg}^{2+}$-ATPase or $\mathrm{Na}^{+}, \mathrm{K}^{+}$ATPase in the erythrocyte ghosts, SERCA1 $\mathrm{Ca}^{2+}, \mathrm{Mg}^{2+}$-ATPase in fast twitch skeletal muscle. Caloxin $3 \mathrm{~A} 1$, based on PED3, inhibits the PMCA pump but not the sarcoplasmic reticulum $\mathrm{Ca}^{2+}$ pump [135].

Interleukin-2 (IL-2), one of the most important cytokines, generally produced by activated helper T-lymphocytes and stimulates proliferation and effector functions of various cells of immune system, has been shown to increase the activity of SR $\mathrm{Ca}^{2+}$-ATPase in rat cardiomyocytes [136].

However, it also decreases the sensitivity of $\mathrm{SR} \mathrm{Ca}^{2+}$ ATPase to calcium. It has been demonstrated that 3,5,3'tri-iodo-L-thyronine (T3), in rat thymocytes, increases plasma membrane $\mathrm{Ca}^{2+}$-ATPase activity [137]. The effect of T3 is rapid, concentration related, evident at a physiological concentration as low as $1 \mathrm{pM}$. The amphiphilic peptide mastoparan, isolated from wasp venom, has been shown to be a potent inhibitor of the sarcoplasmic reticulum $\mathrm{Ca}^{2+}$-ATPase. The peptide also decreases the affinity of the enzyme for $\mathrm{Ca}^{2+}$ and abolishes the cooperativity of $\mathrm{Ca}^{2+}$ binding [138]. Myotoxin a, a polypeptide of 43 amino acids from the prairie rattle snake Crotalus viridis viridis [139] and mellitin, a basic peptide isolated from bee venom inhibit the activity of the $\mathrm{Ca}^{2+}$-ATPase of skeletal muscle sarcoplasmic reticulum [140]. Palytoxin, a coral toxin significantly reduces $\mathrm{Ca}^{2+}$ pumping of isolated SR vesicles [141]. A variety of polyamines, including spermine, spermidine and polyarginine inhibit the $\mathrm{Ca}^{2+}$-ATPase of skeletal muscle [142].

The skeletal muscle SR $\mathrm{Ca}^{2+}$-ATPase is stimulated by jasmine and jasmonate and increase the rate of dephosphorylation of the ATPase [143]. Reports show that ceramide stimulates the plasma membrane $\mathrm{Ca}^{2+}$-ATPase activity in a dose dependent manner and an additive effect in activation was observed in presence of calmodulin and ethanol [144]. Ceramide affects the affinity for $\mathrm{Ca}^{2+}$ and $\mathrm{V}_{\text {max }}$ of the enzyme, and also stimulates $\mathrm{Ca}^{2+}$ transport in inside-out plasma membrane vesicles from erythrocytes. Sphingosine, on the other hand, inhibits the calmodulin stimulated enzyme [141]. Ivermectin, a macrocyclic lactone $\left(\mathrm{IC}_{50}=7 \mu \mathrm{M}\right)$, and cyclosporin $\mathrm{A}$ (a cyclic oligotide) have been shown to be potent inhibittors of SERCA1. Ivermectin inhibition has been shown to be competitive with respect to high concentrations of ATP, increase of $\mathrm{K}_{\mathrm{m}}$ at the regulatory binding site [145].

\section{MECHANISM OF REGULATION}

It is evident from the above discussion that different endogenous regulators modulate various ion transporting enzymes. Questions come, what are the mechanisms of regulation?

$\mathrm{Na}^{+}, \mathrm{K}^{+}$-ATPase has been reported to be inhibited by a number of proteins of varying molecular weights. A 12 $\mathrm{kDa}-13 \mathrm{kDa}$ molecular mass protein from rat brain was found not to compete with ouabain (a specific inhibitor of $\mathrm{Na}^{+}, \mathrm{K}^{+}$-ATPase) in inhibiting the enzyme, whereas, an additive effect was observed in combination with ouabain, suggesting their different binding sites on ATPase. The inhibitor is responsible for controlling the phosphorylation of the ATPase and, thus, its activity and this is due to the binding to $E_{2}$ state of the enzyme. The inhibition was found to be due to conformational change of the ATPase on binding to the inhibitor [105].

Another group of high molecular mass $(70 \mathrm{kDa}-75$ $\mathrm{kDa}$ ) proteins isolated from rat brain and goat spermatozoa cytosol was found to inhibit $\mathrm{Na}^{+}, \mathrm{K}^{+}$-ATPase without having any appreciable effect on $\mathrm{Ca}^{2+}$-ATPase. In both the cases, inhibition was found due to blocking of the phosphorylation step of the overall reaction sequences [106,107]. The one isolated from rat brain $(75 \mathrm{kDa})$ inhibits $\mathrm{Na}^{+}, \mathrm{K}^{+}$-ATPase activity reversibly and binds to the $\mathrm{E}_{2}$ state of the enzyme. CD spectra indicates a slight loss of $\alpha$-helix and random coil in the enzymeinhibitor complex [107]. While the inhibition of the $\mathrm{Na}^{+}$, $\mathrm{K}^{+}$-ATPase by $70 \mathrm{kDa}$ protein isolated from goat spermatozoa was found to be competitive in nature with respect to its substrate, the binding is reversible and inhi- 
bition was found to be due to the change in conformation of the enzyme [106]. The fact that both these inhibitors bind reversibly with the enzyme may act as control element of the transport enzyme and suggests their important role as endogenous regulators.

The SPAIs isolated from porcine duodenum, has been shown to inhibit $\mathrm{Na}^{+}, \mathrm{K}^{+}$-ATPase by the competitive mode against $\mathrm{Na}^{+}$and non-competitive to $\mathrm{K}^{+}$[146]. Another regulator, PE-60 has an activating influence on $\mathrm{Na}^{+}$, $\mathrm{K}^{+}$-ATPase from rat brain frontal cortex, the peptide stimulates the enzyme apparently due to $\mathrm{Na}^{+}$-dependent steps of the $\mathrm{Na}^{+}, \mathrm{K}^{+}$-ATPase system. The activating effect was enhanced by preincubation at low concentrations of ATP that transforms the enzyme into the $\mathrm{Na}^{+}$form [103]. It is obvious that the interactions of PE-60, as well as SPIs, with $\mathrm{Na}^{+}, \mathrm{K}^{+}$-ATPase are relatively complex, both of them exerted their effect by binding to two different sites of the enzyme with different affinities. At low concentration, PEC-60 acts as an activator of the enzyme and at higher concentrations the activating effect is reversed by binding another molecule of PEC-60 [103]. Although SPIs have been reported to inhibit $\mathrm{Na}^{+}$, $\mathrm{K}^{+}$-ATPase, the effect was found to be biphasic, at submicro-molar concentration about $20 \%$ stimulation was observed from intestine whereas at higher peptide concentration inhibition was found [146]. The porcine sperm motility inhibitor (molecular mass, $15 \mathrm{kDa}$ ) is identical to $\beta$-microseminoprotein and is a competitive inhibitor of $\mathrm{Na}^{+}, \mathrm{K}^{+}$-ATPase [85]. With MONaKA, it has been revealed that it binds tightly to the $\beta_{1}$ and $\beta_{3}$ subunits of the $\mathrm{Na}^{+}, \mathrm{K}^{+}$-ATPase. The association between MONaKA and $\mathrm{Na}^{+}, \mathrm{K}^{+}$-ATPase $\beta$-subunit was confirmed by coimmunoprecipitation from transfected cells, mouse brain, and cultured mouse astrocytes [112]. Hormones like aldosterone has been reported to increase the $\mathrm{Na}^{+}$, $\mathrm{K}^{+}$-ATPase function in cultured AT2 cells. This was associated with an increase in the $\beta_{1}$-subunit mRNA levels and $\beta_{1}$-subunit protein abundance in AT2 cell plasma membranes. It has been demonstrated that the human $\mathrm{Na}^{+}, \mathrm{K}^{+}$-ATPase is transcriptionally regulated by aldosterone and may involve a direct interaction with potential hormone response elements present in the promoter region of these genes. Endothelin-1 (ET-1), a hormone, increases the $\mathrm{Na}^{+}, \mathrm{K}^{+}$-ATPase activity in epithelial cells by enhancing the mRNA and protein levels of the $\alpha_{1}$ subunit suggesting ET-1 could play a homeostatic role in modulating aqueous humor formation by having differential effects on the activity and expression of $\mathrm{Na}^{+}, \mathrm{K}^{+}$ATPase by the ciliary epithelium in the eye [89].

FXYD proteins modulate the function of $\mathrm{Na}^{+}, \mathrm{K}^{+}$ATPase by affecting its kinetic properties in specific way. Although effects of FXYD proteins on parameters such as $\mathrm{K}_{1 / 2}^{+}, \mathrm{Na}^{+}{ }_{1 / 2}, \mathrm{~K}_{\mathrm{m}} \mathrm{ATP}$ and $\mathrm{V}_{\max }$ are modest, usually two folds, however these effects may have important longterm consequences for homeostasis of cation balance. Functional modulators are likely to affect the ATPase activity possibly by altering rate limiting steps, particularly the $\mathrm{E}_{1} \mathrm{P}-\mathrm{E}_{2} \mathrm{P}$ and $\mathrm{E}_{2}(\mathrm{~K})-\mathrm{E}_{1}$ conformational transitions, or binding of the transported cations, particularly cytoplasmic $\mathrm{Na}^{+}$ions (or competing $\mathrm{K}^{+}$ions), which may limit the rate of active $\mathrm{Na}^{+}$pumping in vivo. Although some conclusions on the effects of FXYD on cation binding and conformational transitions have been drawn, direct observations with purified $\alpha / \beta /$ FXYD complexes would be more conclusive [44].

Evidence suggests multiple sites of interactions between FXYD and $\alpha / \beta$ subunits. Data supporting this came from the fact that the anti- $\gamma \mathrm{C}$ terminus neutralizes the effect of $\gamma$ on the apparent ATP affinity in renal $\mathrm{Na}^{+}$, $\mathrm{K}^{+}$-ATPase or HeLa cells transfected with $\gamma$, but not with $\mathrm{K}^{+}: \mathrm{Na}^{+}$antagonism $[16,44]$. Expression in HeLa cells of $\gamma$ with either 4 or $10 \mathrm{C}$-terminal residues or 7-deleted $\mathrm{N}$ terminal residues removes the effect of $\gamma$ on ATP affinity but does not affect the $\mathrm{K}^{+}: \mathrm{Na}^{+}$antagonism. Replacement of the deleted $7 \mathrm{~N}$-terminal residues with 7 alanines restores the effect on ATP affinity [93].

Mutational analysis combined with expression in Xenopus oocytes reveals that $\mathrm{Phe}^{956}, \mathrm{Glu}^{960}$, $\mathrm{Leu}^{964}$, and $\mathrm{Phe}^{967}$ in TM9 of the $\mathrm{Na}^{+}, \mathrm{K}^{+}$-ATPase $\alpha$ subunit represent one face interacting with the three FXYD proteins i.e. FXYD2, FXYD4, and FXYD7. Leu ${ }^{964}$ and Phe ${ }^{967}$ contribute to the efficient association of FXYD proteins with the $\mathrm{Na}^{+}, \mathrm{K}^{+}$-ATPase $\alpha$ subunit, whereas Phe ${ }^{956}$ and $\mathrm{Glu}^{960}$ are essential for the transmission of the functional effect of FXYD proteins on the apparent $\mathrm{K}^{+}$affinity of $\mathrm{Na}^{+}, \mathrm{K}^{+}$-ATPase. The relative contribution of $\mathrm{Phe}^{956}$ and $\mathrm{Glu}^{960}$ to the $\mathrm{K}^{+}$effect differs for different FXYD proteins, due to the intrinsic differences of FXYD proteins on the apparent $\mathrm{K}^{+}$affinity of $\mathrm{Na}^{+}, \mathrm{K}^{+}$-ATPase. In contrast to the effect on the apparent $\mathrm{K}^{+}$affinity, $\mathrm{Phe}^{956}$ and $\mathrm{Glu}^{960}$ are not involved in the effect of FXYD2 and FXYD4 on the apparent $\mathrm{Na}^{+}$affinity of $\mathrm{Na}^{+}, \mathrm{K}^{+}$-ATPase. The mutational analysis followed by a docking model of the $\mathrm{Na}^{+}, \mathrm{K}^{+}$-ATPase/FXYD7 complex, predicted the importance of $\mathrm{Phe}^{956}$, Glu ${ }^{960}$, $\mathrm{Leu}^{964}$, and $\mathrm{Phe}^{967}$ in subunit interaction [147]. It has been suggested that FXYD proteins modulate $\mathrm{Na}^{+}, \mathrm{K}^{+}$-ATPase activity in close cooperation with post-translational modifications such as phosphorylation [148].

Recent study shows FXYD1 associated with the $\mathrm{Na}^{+}$, $\mathrm{K}^{+}$-ATPase $\alpha$ and $\beta$ subunits, and that the effects of phosphorylation by PKA on the $\mathrm{Na}^{+}, \mathrm{K}^{+}$-ATPase regulatory activity of FXYD1 could be due primarily to changes in electrostatic potential near the membrane surface and near the $\mathrm{Na}^{+} / \mathrm{K}^{+}$ion binding site of the $\mathrm{Na}^{+}, \mathrm{K}^{+}$-ATPase $\alpha$ subunit [149]. Furthermore, protein kinase phos- 
phorylation also seems to involve direct modification of $\mathrm{Na}^{+}, \mathrm{K}^{+}$-ATPase catalytic activity both in vitro and in vivo, at least in some systems [149]. Interestingly, FXYD proteins are found to be involved in the regulation of some diseases. Recently Okudela et al. [150] has reported that FXYD3 levels were also lower in a considerable proportion in primary lung cancers than in nontumoral airway epithelia; its expression levels decreased in parallel with the dedifferentiation process. Therefore, it was suggested that inactivation of FXYD3 through a gene mutation or unknown mechanism could be one of the causes of the atypical shapes of cancer cells and play a potential role in the progression of lung cancer.. The latest addition of FXYD11 gene (zFXYD11) regulating the transport ability of NaK-MRCs (mitochondrion-rich cells) by modulating $\mathrm{Na}^{+}, \mathrm{K}^{+}$-ATPase activity may be involved in the controlling of body fluid and electrolyte homeostasis [151].

Anionic phospholipids increase the intermolecular cross-linking between the FXYD10 C-terminus (Cys74) and the Cys254 in the $\mathrm{Na}^{+}, \mathrm{K}^{+}$-ATPase (in shark) Adomain. However it has been suggested that phosphorylation involves only modest structural rearrangements between the cytoplasmic domain of FXYD10 and the $\mathrm{Na}^{+}, \mathrm{K}^{+}$-ATPase A-domain [147]. The salinity-dependent expression of pFXYD (pufferfish FXYD gene) protein and $\mathrm{Na}^{+}, \mathrm{K}^{+}$, as well as the evidence for their co-localization and interaction in pufferfish gills suggested that pFXYD regulates $\mathrm{Na}^{+}, \mathrm{K}^{+}$-ATPase activity in gills of euryhaline teleosts upon salinity challenge [152].

The ATPase described here gets phophorylated by different protein kinases for their function. The protein kinase $\mathrm{A} /$ protein kinase $\mathrm{C}$ (PKA/PKC) phosphorylation profile of $\mathrm{H}^{+}, \mathrm{K}^{+}$-ATPase is very similar to the one found in the $\mathrm{Na}^{+}, \mathrm{K}^{+}$-ATPase. PKC phosphorylation is taking place in the N-terminal part of the $\alpha$-subunit with a stoichiometry of $0.6 \mathrm{~mol} \mathrm{Pi} /$ mole $\alpha$-subunit. PKA phosphorylation is in the $\mathrm{C}$-terminal part and requires detergent, as is also found for the $\mathrm{Na}^{+}, \mathrm{K}^{+}$-ATPase. The stoichiometry of PKA-induced phosphorylation was $0.7 \mathrm{~mol}$ $\mathrm{Pi} /$ mole $\alpha$-subunit. The $\mathrm{Na}^{+}, \mathrm{K}^{+}$-ATPase is also known to be regulated by membrane trafficking controlled by $\mathrm{N}$ terminal PKC phosphorylation [63] through a mechanism that involves binding of phosphoinositide 3-kinase to a polyproline motif in the N-terminus [153]. Controlled proteolysis of the N-terminus abolished PK C phosphorylation of native $\mathrm{H}^{+}, \mathrm{K}^{+}$-ATPase [102].

A number of low molecular mass proteins reported from the author's laboratory has been found to affect $\mathrm{Mg}^{2+}, \mathrm{Ca}^{2+}$-ATPase and $\mathrm{Ca}^{2+}$-ATPase differentially. One, molecular mass of $12 \mathrm{kDa}$ from rat brain has been reported to stimulate $\mathrm{Ca}^{2+}, \mathrm{Mg}^{2+}$-ATPase and inhibit $\mathrm{Ca}^{2+}$ -ATPase (SERCA family), the binding between enzymes and the protein was found to be reversible and non- competitive in nature. The modulator was found to be negatively charged protein and could be a good tool in distinguishing the regulation of these two ATPases [37]. On the other hand, a protein with molecular mass 13,961 from goat testes cytosol [122] has been found to stimulate $\mathrm{Mg}^{2+}$-independent $\mathrm{Ca}^{2+}$-ATPase without having any appreciable effect on $\mathrm{Mg}^{2+}$-dependent one. The stimultorbinds to a single site of the enzyme. The effect was due to enhancement of the dephosphorylation rate of the overall reaction steps and acceleration of the calcium uptake [123]. Another $14 \mathrm{kDa}$ mass stimulator of $\mathrm{Mg}^{2+}$-independent $\mathrm{Ca}^{2+}$-ATPase (belongs to SERCA family) has been reported by Ghoshal et al. [124,125] from bovine brain and was found to enhance the $\mathrm{Ca}^{2+}$-uptake. It also stimulates sperm motility suggesting its role in fertility. Proteomic analysis suggests its similarity with thyroid hormone-responsive protein [154]. The effects in both the above cases were found to be non-species specific against SERCA.

Myotoxin a, a polypeptide from the prairie rattle snake was found to inhibit $\mathrm{Ca}^{2+}$-ATPase by decreasing the rate of dephosphorylation, with no effect on the $\mathrm{Ca}^{2+}$. transport step ]139].

Based on the findings of the author's laboratory, following schemes (Figures 3(a) and (b)) have been proposed for the regulation of $\mathrm{Mg}^{2+}$-independent and $\mathrm{Mg}^{2+}$ dependent $\mathrm{Ca}^{2+}$-ATPases by various endogenous modulator proteins.

Each of the modulator reported from the author's laboratory $[37,105-107,122,124]$ has been found to bind to the respective ATPase in a reversible manner. Thus it has been hypothesized that they can act as endogenous regulators of the ATPases. Moreover, an "on" and "off" type of mechanism has been proposed, whereby the modulator remains inactive under normal condition (off). It gets activated (on) when a malfunction of the ATPase/ pump occurs, binds to the enzyme, brings it to the normal condition then dissociates. A cartoon as shown below in Figure $\mathbf{4}$ has been proposed.

The most important among the regulators of $\mathrm{Ca}^{2+}$ ATPase is calmodulin. The PMCA pump has high affinity for $\mathrm{Ca}^{2+}\left(\mathrm{K}_{\mathrm{m}}<0.5 \mu \mathrm{M}\right)$ when complexed with calmodulin, the physiological activator of the pump [155]. Calmodulin stimulates the $\mathrm{V}_{\max }$ of the enzyme, but especially decreases the $\mathrm{K}_{\mathrm{m}}\left(\mathrm{Ca}^{2+}\right)$ by one order of magnitude i.e. from about $10 \mu \mathrm{M}-20 \mu \mathrm{M}$ to about $0.5 \mu \mathrm{M}$. The pump interacts with calmodulin in a $\mathrm{Ca}^{2+}$-dependent manner and has high affinity for it: a $\mathrm{K}_{\mathrm{d}}$ of about $1 \mathrm{nM}$ has been observed [53]. The regulation of the pump by calmodulin binding in its $\mathrm{C}$-terminal tail provides a striking example of the autoregulation of the $\mathrm{Ca}^{2+} \cdot \mathrm{Ca}^{2+}$. calmodulin binds to a region in the $\mathrm{COOH}$-terminal portion of the PMCAs, located $\sim 40$ residues downstream of the last transmembrane domain[156]. In the absence of 

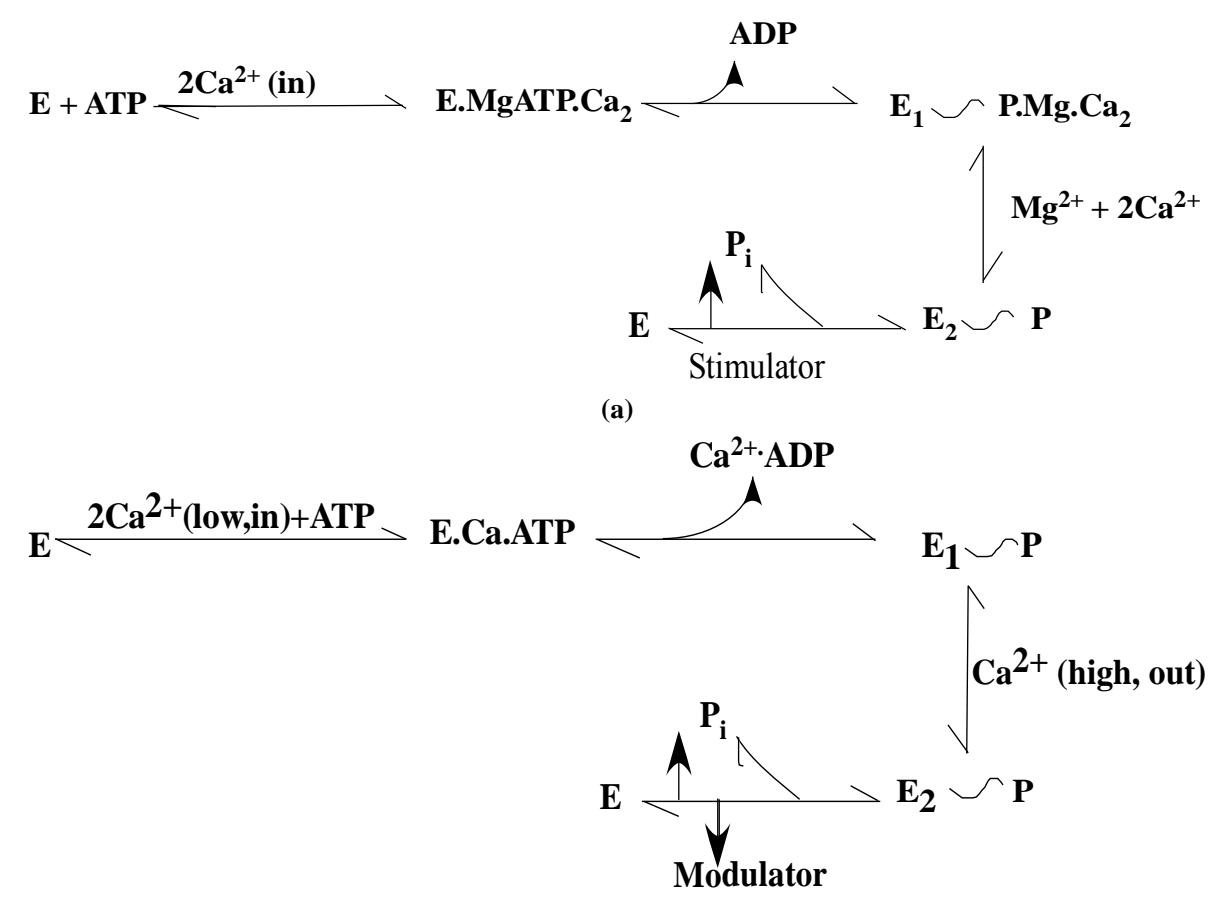

(b)

Figure 3. (a) $\mathrm{Mg}^{2+}$-dependent $\mathrm{Ca}^{2+}$-ATPase. Phosphorylation is followed by a complex formed in presence of $\mathrm{Mg}^{2+}$ and ATP followed by dephosphorylation. Endogenous protein was found to stimulate ( $\uparrow$ ) the enzyme activity. (b) $\mathrm{Mg}^{2+}$-independent $\mathrm{Ca}^{2+}$-ATPase. Phosphorylation and dephosphorylation are controlled by low (high affinity) and high (low affinity) concentration of $\mathrm{Ca}^{2+}$. The modulator proteins can either stimulate $(\uparrow)$ or inhibit $(\downarrow)$ the enzyme activities.

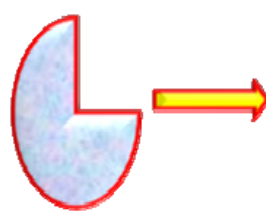

ATPase

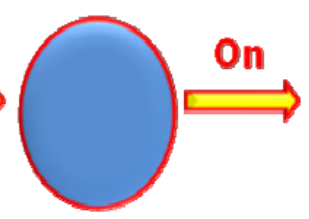

Modulator

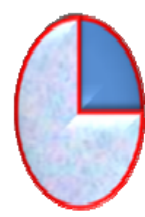

Off

ATPase + Modulator

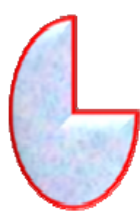

ATPase

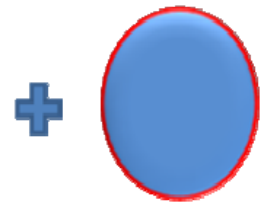

Modulator

Figure 4. A schematic model showing binding of the modulator with the ATPase and its dissociation.

$\mathrm{Ca}^{2+}$-calmodulin, this sequence acts as an "autoinhibitory domain"; cross-linking studies using labeled peptides demonstrated that the calmodulin binding domain interacts intramolecularly with two separate regions of the pump, one located in the first cytosolic loop and the other in the major catalytic unit between the phosphorylation and the ATP binding site [155]. This intramolecular interaction probably hinders the access of $\mathrm{Ca}^{2+}$ and/or ATP to the active site, preventing catalytic turnover, keeping the pump in an inhibited state. An elevation in the cytoplasmic $\mathrm{Ca}^{2+}$ results in an increase in $\mathrm{Ca}^{2+}$-calmodulin, which then binds with high affinity to the autoinhibitory domain of the PMCA, thereby releasing the inhibition and stimulating pump activity to near-maximal potential.

The peptide, caloxin inhibits $\mathrm{Ca}^{2+}, \mathrm{Mg}^{2+}$-ATPase activity in leaky erythrocyte ghosts with a $\mathrm{K}_{\mathrm{i}}$ value of 0.4 $\mathrm{mmol} / \mathrm{L}-0.8 \mathrm{mmol} / \mathrm{L}$. The inhibition is noncompetitive with respect to the substrates and calmodulin [157]. Caloxin1A1 inhibits PMCA by binding to the first extracellular domain [135] while caloxin1B1 is isoform selective with a higher affinity for PMCA4 than PMCA1 [158]. The effect of spermine, particularly, is highly specific; inhibition resulting from the decrease in the rate of dissociation of $\mathrm{Ca}^{2+}$ from the phosphorylated ATPase $\left(\mathrm{Ca}_{2} \mathrm{E}_{1} \mathrm{P} \rightarrow \mathrm{E}_{2} \mathrm{P}\right)$ [142]. It has been suggested that regucalcin (maintains intracellular $\mathrm{Ca}^{2+}$-homeostasis) may act on the SH groups of $\mathrm{Ca}^{2+}$-ATPase by binding to microsomal membranes [119]. Effects of different endogenous modulators on affecting activities and/or affinities of the enzymes to the substrate and/or co-factors are shown in Tables 1 and 2. 
Table 1. Effects of different modulators on the activities and kinetic pameters of $\mathrm{Na}^{+}, \mathrm{K}^{+}$-ATPase. $\uparrow$ stimulation and $\downarrow$ inhibition of the enzyme activities.

\begin{tabular}{|c|c|c|c|c|}
\hline Modulators & Enzymes & Kinetic parameters change & Activity $(\uparrow \downarrow)$ & Refs. \\
\hline \multirow{3}{*}{ FXYD1 } & $\mathrm{Na}^{+}, \mathrm{K}^{+}$-ATPase & $\mathrm{K}_{1 / 2} \mathrm{Na}^{+}$ & - & [93] \\
\hline & (rat kidney, bovine and rat cardiac sarcolema); & $\mathrm{K}_{1 / 2} \mathrm{~K}^{+}$ & & \\
\hline & rat cardiac $\mathrm{Na}^{+}, \mathrm{K}^{+}$-ATPase & - & $\uparrow$ & [159] \\
\hline \multirow{3}{*}{ FXYD2 } & $\mathrm{Na}^{+}, \mathrm{K}^{+}$-ATPase (renal) & $\mathrm{K}_{\mathrm{m}} \mathrm{ATP}$ & - & [94] \\
\hline & knockout mouse & $\mathrm{K}_{1 / 2} \mathrm{Na}^{+}$ & - & [94] \\
\hline & (kidney membrane) & $\mathrm{K}_{\mathrm{m}} \mathrm{ATP}$ & & \\
\hline \multirow{2}{*}{ FXYD3 } & $\mathrm{Na}^{+}, \mathrm{K}^{+}$-ATPase & $\mathrm{K}_{1 / 2} \mathrm{Na}^{+}$ & & \\
\hline & (X.oocytes) & $\mathrm{K}_{1 / 2} \mathrm{~K}^{+}$ & & \\
\hline FXYD4 & $\mathrm{Na}^{+}, \mathrm{K}^{+}$-ATPase (mammalian) & $\mathrm{K}_{1 / 2} \mathrm{Na}^{+}$ & - & [160] \\
\hline FXYD7 & $\mathrm{Na}^{+}, \mathrm{K}^{+}$-ATPase (brain) & $\mathrm{K}_{1 / 2} \mathrm{~K}^{+}$ & - & [100] \\
\hline \multirow{2}{*}{ SPAI-1 } & $\mathrm{Na}^{+}, \mathrm{K}^{+}$-ATPase & $\mathrm{K}_{1 / 2} \mathrm{Na}^{+}$ & $\downarrow$ & [114] \\
\hline & (mammalian kidney & $\mathrm{K}_{1 / 2} \mathrm{~K}^{+}$ & & \\
\hline $12 \mathrm{kDa}-13 \mathrm{kDa}$ & $\mathrm{Na}^{+}, \mathrm{K}^{+}$-ATPase & $\mathrm{K}_{1 / 2} \mathrm{Na}^{+}$ & $\downarrow$ & [105] \\
\hline Protein (rat brain) & (rat brain) & $\mathrm{K}_{1 / 2} \mathrm{~K}^{+}$ & & \\
\hline $75 \mathrm{kDa}$ protein & $\mathrm{Na}^{+}, \mathrm{K}^{+}$-ATPase & $\mathrm{K}_{1 / 2} \mathrm{Na}^{+}$ & $\downarrow$ & [107] \\
\hline (rat brain) & (rat brain) & $\mathrm{K}_{1 / 2} \mathrm{~K}^{+}$ & & \\
\hline $70 \mathrm{kDa}$ protein & $\mathrm{Na}^{+}, \mathrm{K}^{+}$-ATPase & $\mathrm{K}_{1 / 2} \mathrm{Na}^{+}$ & $\downarrow$ & [106] \\
\hline (goat testis) & (rat brain) & $\mathrm{K}_{1 / 2} \mathrm{~K}^{+}$ & & \\
\hline
\end{tabular}

Table 2. Effects of different modulators on the activities and kinetic pameters of $\mathrm{Mg}^{2+}$-independent and $\mathrm{Mg}^{2+}$-dependent $\mathrm{Ca}^{2+}$-ATPases. $\uparrow$ stimulation and $\downarrow$ inhibition of the enzyme activities.

\begin{tabular}{|c|c|c|c|c|}
\hline Modulators & Enzymes & Kinetic parameters change & Activity $(\uparrow \downarrow)$ & Refs. \\
\hline PDC-109 & $\mathrm{Mg}^{2+}$-independent & $\mathrm{K}_{\mathrm{m}} \mathrm{ATP}$ & $\uparrow$ & {$[33]$} \\
\hline (bovine seminal and dependent vesicles) & $\begin{array}{c}\mathrm{Ca}^{2+} \text {-ATPase } \\
\text { (bovine spermatozoa) }\end{array}$ & & & \\
\hline $12 \mathrm{kDa}$ protein & $\mathrm{Mg}^{2+}$-independent & $\mathrm{K}_{1 / 2} \mathrm{Ca}^{2}$ & $\downarrow$ & {$[37]$} \\
\hline \multirow[t]{4}{*}{ (rat brain) } & $\mathrm{Ca}^{2+}$-ATPase & $\mathrm{K}_{\mathrm{m}} \mathrm{ATP}$ & & \\
\hline & $\mathrm{Mg}^{2+}$-dependent & & & \\
\hline & $\mathrm{Ca}^{2+}$-ATPase & $\mathrm{K}_{1 / 2} \mathrm{Ca}^{2+}$ & $\uparrow$ & [37] \\
\hline & (goat spermatozoa) & $\mathrm{K}_{\mathrm{m}} \mathrm{ATP}$ & & \\
\hline $4 \mathrm{kDa}$ protein & $\mathrm{Mg}^{2+}$-independent & $\mathrm{K}_{1 / 2} \mathrm{Ca}^{2+}$ & $\uparrow$ & {$[124]$} \\
\hline (bovine brain) & $\mathrm{Ca}^{2+}$-ATPase & & & \\
\hline $4 \mathrm{kDa}$ protein & $\mathrm{Mg}^{2+}$-independent & $\mathrm{K}_{1 / 2} \mathrm{Ca}^{2+}$ & $\uparrow$ & {$[122]$} \\
\hline (goat testis) & $\mathrm{Ca}^{2+}$-ATPase & & & \\
\hline
\end{tabular}


Two other low molecular weight proteins which can modulate SERCA pump activities are phospholamban and sarcolipin [161,162]. In vitro, phospholamban inhbits SERCA1 and SERCA2, but not SERCA3. The phosphorylation of phospholamban by the catalytic subunit of the cAMP-dependent protrein kinase reverses the inhibitory effect of $\mathrm{Ca}^{2+}$-pump. This suggests that phosphorylation of an inhibitor of the $\mathrm{Ca}^{2+}$-ATPase in cardiac SR and dephopshorylation relieves its inhibition. The direct interaction between hydrophilic portion of PLN may be one of the mechanisms of the regulation. It is clear that SERCA2a and PLN have a critical role in $\mathrm{SR} \mathrm{Ca}^{2+}$ cycling and contractility. Thus, elucidating more specific roles that these proteins play in the development of cardiomyopathy may aid in development and improvement of drugs for the treatment of cardiac disease, and ultimately lead to the generation of novel genetic therapy for human heart failure [129]. PLN binding inhibits the $\mathrm{Ca}^{2+}$ pumps by lowering their $\mathrm{Ca}^{2+}$ affinity [161]. It can exist as a monomer or as a pentamer and it is the latter which appears to be responsible for the inhibition [163]. The transmembrane interaction sites (a residue, 31 - 52) were also shown to mediate the regulatory effects of PLN on SERCA2a affinity, with some mutations yielding increased inhibition while others abolished the PLN inhibitory effects on SERCA2a in vitro [164]. The total expression levels of one phospholamban per $\mathrm{Ca}^{2+}$-ATPase result in full inhibition of the enzyme activity. The excess PLN expressed in the heart over that required for inhibition suggests a capability for graded responses of the $\mathrm{Ca}^{2+}$-ATPase activity to endogenous kinases and phosphatases that modulate the level of phosphorylation necessary to relieve inhibition of the $\mathrm{Ca}^{2+}$ ATPase by PLN [165]. Mutagenesis studies show the SERCA sequence Lys ${ }^{397}$-Asp Acid-Asp Acid-Lys-Pro$\mathrm{Val}^{402}$ are essential for regulation by phospholamban [133]. This sequence interacts with the cytoplasmic domain of phospholamban. Since this sequence is missing in SERCA3, it is not inhibited by PLN. It interacts with the SERCA pump both at the cytosolic nucleotide binding domain (Lys ${ }^{400}$ in the $\mathrm{N}$ domain) [166] and with the transmembrane sector, maintaining the pump in an inhibited state. The inhibition is removed by phosphorylation of residues $\mathrm{Ser}^{16}, \mathrm{Thr}^{17}$ and $\mathrm{Ser}^{10}$ in the hydrophilic portion by protein kinase $\mathrm{A}$, a $\mathrm{Ca}^{2+} /$ calmodulin-dependent kinase-II and protein kinase $\mathrm{C}$ respectively. The phosphorylation is assumed to induce a conformational change of PLN that forces its detachment from the pump both at the cytosolic and the transmembrane interacting sites. PLN can be again dephosphorylated by protein phosphatases.

Sarcolipin is a 31 amino acid peptide expressed predominantly in the fast twitch skeletal muscle [167], al- though in vitro it inhibits SERCA1 or SERCA2 pump activity. Amino acid sequence comparison and modeling studies have shown that the transmembrane helices of SLN and PLN share considerable homology, suggesting both proteins interact in a similar way with SERCA [128, 168-170]. A recent study suggests that the lumenal domain could be involved in the retention of SLN in the ER, although it might have a different function too [171]. The flexible nature of the C-terminus also leaves Tyr-29 and Tyr-31 residues available for interactions with various aromatic residues in the transmembrane helices of SERCA and suggests that lumenal domain could be involved in the regulation of SERCA-SLN interaction $[128,171]$. Recently Morita et al has proposed the interactions among PLN, NF-SLN and SERCA1a and found that mutation of amino acids $\mathrm{Ile}^{40}, \mathrm{Ile}^{47}$, and $\mathrm{Ile}^{48}$ in PLN and mutation of $\mathrm{Val}^{19}, \mathrm{Ile}^{22}$ and $\mathrm{Trp}^{23}$ in NF-SLN diminished either the super-inhibition imposed on SERCA1a function by the PLN-NF-SLN binary complex or the physical interactions between PLN and NF-SLN or both [172].

\section{CONCLUSIONS}

The foregoing discussion along with the supporting information suggest that endogenous modulators of varying molecular masses regulate ATPase activities and are believed to act as physiological regulators of different ATPases. The question may be raised whether the modulator(s) particularly when they are proteins would reach the target site in their native form when use from outside since they may be degraded by proteolysis. The other possibility is to develope antibody against these modulators due to prolong use of them.

However, inspite of these short comings, protein regulators may be useful tool for develping drugs with better acceptability since they are endogenous in nature. We have found that one of the modulators of $\mathrm{Ca}^{2+}$-ATPase [37] can act as a female contraceptive agent when tested on rat and rabbit. An Indian patent has been awarded on this work. Simuilarly, it is clear that SERCA2a and PLN have a critical role in SR $\mathrm{Ca}^{2+}$ cycling and contractility. Thus, elucidating more specific roles that these proteins play in inducing cardiomyopathy may aid in development and improvement of drugs for the treatment of cardiac disease, and ultimately lead to the generation of novel genetic therapy for human heart failure [131]. SERCA is responsible for the reuptake of cytoplasmic $\mathrm{Ca}^{2+}$ in muscle, where it ensures the efficient relaxation at the end of a contraction event. Recently it has been reported that FXYD3 levels were decreased in a considerable proportion of primary lung cancers than in nontumoral airway epithelia. Its expression levels decreased in parallel with the dedifferentiation process. 
Therefore, it has been suggested that inactivation of FXYD3 through a gene mutation or unknown mechanism could be one of the reasons of the atypical shapes of cancer cells and play a potential role in the progresssion of lung cancer [150]. Therefore activation of FXYD3 by any out side agent may provide a lead of developing an anticancer drug.

Hence, it may be suggested that some of these modulators may be utilized as drug against a specific disease which is considered to be quite important and interesting from physiological, biochemical and medicinal point of view.

\section{ACKNOWLEGDEMENTS}

The work in the author's laboratory was supported by Bose Institute and a part by a project from Council of Scientific and Industrial Research [EMR-37 (1299)/07)]. The author is thankful to Dr. Atin K. Mandal, Ms Pinki Nandi and Ms Swatilekha Ghosh, Division of Molecular Medicine, for comments, criticism and meaningful discussion during preparation of the article.

\section{REFERENCES}

[1] Kuhlbrandt, W., (2004) Biology, structure and mechanism of P-type ATPases. Nature Review Molecular and Cell Biology, 5, 282-295. doi:10.1038/nrm1354

[2] Tempel, B.L. and Shilling, D.J. (2007) The plasma membrane calcium ATPase and disease. Subcellular Biochemistry, 45, 365-383.

doi:10.1007/978-1-4020-6191-2_13

[3] xelsen, K.B. and Palmgren, M.G. (1998) Evolution of substrate specificities in the P-type ATPase superfamily. Journal Molecular Evolution, 46, 84-101.

[4] De Weer, P. (1985) The Kidney. In Seldin, D.W. and Geibisch, G., Eds., Physiology and Pathophysiology, Raven Press, NewYork, 31.

[5] Therien, A.G., Pu, H.X., Karlish, S.J. and Blostein, R. (2001) Molecular and functional studies of the gamma subunit of the sodium pump. Journal of Bioenergetics and Biomembranes, 33, 407-414. doi:10.1023/A:1010619623841

[6] Sweadner, K.J. and Rael, E., (2000) The FXYD gene family of small ion transport regulators or channels: cDNA sequence, protein signature sequence, and expression. Ge-nomics, 68, 41-56. doi:10.1006/geno.2000.6274

[7] Blanco, G., Melton, R.J., Sanchez, G. and Mercer, R.W. (1999) Functional characterization of a testes-specific alpha-subunit isoform of the sodium/potassium adenosinetriphosphatase. Biochemistry, 38, 13661-13669. doi:10.1021/bi991207b

[8] Woo, A.L., James, P.F. and Lingrel, J.B. (2000). Sperm motility is dependent on a unique isoform of the $\mathrm{Na}^{+}$, $\mathrm{K}^{+}$-ATPase. Journal of Biological Chemstry, 275, 2069320699. doi:10.1074/jbc.M002323200

[9] Good, P.J., Richter, K. and Dawid, I.B. (1990) A nervous system-specific isotype of the beta subunit of $\mathrm{Na}^{+}$, $\mathrm{K}^{+}$-ATPase expressed during early development of Xeno- pus laevis. Proceedings of the National Academy of Sciences of the USA, 87, 9088-9092.

doi:10.1073/pnas.87.23.9088

[10] Pestov, N.B., Adams, G., Shakhparonov, M.I. and Modyanov, N.N. (1999) Identification of a novel gene of the $\mathrm{Na}, \mathrm{K}^{+}$-ATPase beta-subunit family that is predominantly expressed in skeletal and heart muscles. FEBS Letters, 456, 243-248. doi:10.1016/S0014-5793(99)00954-0

[11] Eakle, K.A., Kabalin, M.A., Wang, S.G. and Farley, R.A. (1994) The influence of beta subunit structure on the stability of $\mathrm{Na}^{+}, \mathrm{K}^{+}$-ATPase complexes and interaction with $\mathrm{K}^{+}$. Journal of Biological Chemistry, 269, 6550-6557.

[12] Crambert, G., Beguin, P., Uldry, M., Monnet-Tschudi, F., Horisberger, J.D., Garty, H. and Geering, K. (2003) FXYD7, the first brain- and isoform-specific regulator of $\mathrm{Na}^{+}, \mathrm{K}^{+}$-ATPase: Biosynthesis and function of its posttranslational modifications. Annual New York Academy of. Sciences, 986, 444-448

[13] Garty, H. and Karlish, S.J. (2005) FXYD proteins: Tissue-specific regulators of the $\mathrm{Na}^{+}, \mathrm{K}^{+}$-ATPase. Seminars in Nephrology, 25, 304-311. doi:10.1016/j.semnephrol.2005.03.005

[14] Williams, R.J.P. (1999) Calcium as a cellular regulator. In: Carafoli, E. and Klee C., Eds., Oxford University Press, New York, 3-27.

[15] Carafoli, E. (2004) Calcium-mediated cellular signals: a story of failures. Trends Biochemical Sciences, 29, 371379. doi:10.1016/j.tibs.2004.05.006

[16] Philipson, K.D. and Nicoll, D.A. (2000) Sodium-calcium exchange: A molecular perspective. Annual Review of Physiology, 62, 111-133. doi:10.1146/annurev.physiol.62.1.111

[17] Toyoshima, C., Nakasako, M., Nomura, H. and Ogawa, H. (2000) Crystal structure of the calcium pump of sarcoplasmic reticulum at 2.6 A resolution. Nature, 405, 647-655. doi: $10.1038 / 35015017$

[18] Toyoshima, C. and Nomura, H. (2002) Structural changes in the calcium pump accompanying the dissociation of calcium. Nature, 418, 605-611. doi:10.1038/nature00944

[19] Toyoshima, C. and Mizutani, T. (2004) Crystal structure of the calcium pump with a bound ATP analogue. Nature, 430, 529-535. doi: $10.1038 /$ nature 02680

[20] Lee, A.G. (2002) $\mathrm{Ca}^{2+}$-ATPase structure in the $\mathrm{E}_{1}$ and $\mathrm{E}_{2}$ conformations: Mechanism, helix-helix and helixlipid interactions. Biochimica et Biophysica Acta, 1565, 246266. doi:10.1016/S0005-2736(02)00573-4

[21] Verma, A.K., Filoteo, A.G., Stanford, D.R., Wieben, E.D., Penniston, J.T., Strehler, E.E., Fischer, R., Heim, R., Vogel, G., Mathews, S., et al. (1988) Complete primary structure of a human plasma membrane $\mathrm{Ca}^{2+}$ pump. Journal of Biological Chemistry, 263, 14152-14159.

[22] Graf, E., Verma, A.K., Gorski, J.P., Lopaschuk, G., Niggli, V., Zurini, M., Carafoli, E. and Penniston, J.T. (1982) Molecular properties of calcium-pumping ATPase from human erythrocytes. Biochemistry, 21, 4511-4516. doi:10.1021/bi00261a049

[23] Sumbilla, C., Lewis, D., Hammerschmidt, T. and Inesi, G. (2002) The slippage of the $\mathrm{Ca}^{2+}$ pump and its control by anions and curcumin in skeletal and cardiac sarcoplasmic 
reticulum. Journal of Biological Chemistry, 277, 1390013906. doi:10.1074/jbc.M111155200

[24] Lutsenko, S. and Kaplan, J.H. (1995) Organization of P-type ATPases: Significance of structural diversity. Biochemistry, 34, 15607-15613. doi:10.1021/bi00048a001

[25] Strehler, E.E. and Zacharias, D.A. (2001) Role of alternative splicing in generating isoform diversity among plasma membrane calcium pumps. Physiological Review, 81, 21-50.

[26] Vijayasarathy, S., Shivaji, S. and Balaram, P. (1980) Plasma membrane bound $\mathrm{Ca}^{2+}$-ATPase activity in bull sperm. FEBS Letters, 114, 45-47. doi:10.1016/0014-5793(80)80857-X

[27] Hjerten, S. and Pan, H. (1983) Purification and characterization of two forms of a low-affinity $\mathrm{Ca}^{2+}$-ATPase from erythrocyte membranes. Biochimimical et Biophysica Acta, 728, 281-288. doi:10.1016/0005-2736(83)90480-7

[28] Kwan, C.Y. and Kostka, P. (1984) $\mathrm{A} \mathrm{Mg}^{2+}$-independent high-affinity $\mathrm{Ca}^{2+}$-stimulated adenosine triphosphatase in the plasma membrane of rat stomach smooth muscle. Subcellular distribution and inhibition by $\mathrm{Mg}^{2+}$. Biochimica et Biophysica Acta, 776, 209-216. doi:10.1016/0005-2736(84)90210-4

[29] Ghijsen, W., Gmaj, P. and Murer, H. (1984) $\mathrm{Ca}^{2+}$-stimulated, $\mathrm{Mg}^{2+}$-independent ATP hydrolysis and the high affinity $\mathrm{Ca}^{2+}$-pumping ATPase. Two different activities in rat kidney basolateral membranes. Biochimical et Biophysic Acta, 778, 481-488.

[30] Gandhi, C.R. and Ross, D.H. (1988) Characterization of a high-affinity $\mathrm{Mg}^{2+}$-independent $\mathrm{Ca}^{2+}$-ATPase from rat brain synaptosomal membranes. Journal of Neurochemistry, 50, 248-256. doi:10.1111/j.1471-4159.1988.tb13257.x

[31] Vanithakumari, G. and Govindarajulu, P. (1985) Adenosine triphosphatase systems in genital tract of testosterone treated male adult monkeys. Indian Journal of Physiology and Pharmacology, 29, 1-6.

[32] Post, H., Wiche, R., Sen, P.C., Hoffbauer, G., Albrecht, M., Seitz, J., Aumuller, G. and Wilhelm, B. (2002) Identification of a plasma membrane $\mathrm{Ca}^{2+}$-ATPase in epithetlial cells and aposomes of the rat coagulating gland. Prostate, 52, 159-166. doi:10.1002/pros.10109

[33] Sanchez-Luengo, S., Aumuller, G., Albrecht, M., Sen, P.C., Rohm, K. and Wilhelm, B. (2004) Interaction of PDC-109, the major secretory protein from bull seminal vesicles, with bovine sperm membrane $\mathrm{Ca}^{2+}$-ATPase. Journal of Andrology, 25, 234-244.

[34] Da Silva, R.S., de Paula C.G., Bogo, M.R., Da Silva R.S., de Paula-Cognato, G., Bogo, M.R., da Graca-Fauth, M., Fin, C.A., Thome, J.W., Bonan, C.D., da Graca, F.M., Fin, C.A., Thome, J.W., Bonan, C.D. and Dutra, D.R. (2002) Unique $\mathrm{Ca}^{2+}$-activated ATPase in the nervous ganglia of Phyllocaulis soleiformis (Mollusca). Comparative Biochemistryand Physiology B, 131, 55-61.

[35] NagDas, S.K., Mukherjee, S., Mazumder, B. and Sen, P. C. (1988) Identification and characterization of a $\mathrm{Mg}^{2+}$ dependent and an independent $\mathrm{Ca}^{2+}$-ATPase in microsomal membranes of rat testis. Molecularl and Cellular Biochemistry, 79, 161-169. doi:10.1007/BF02424559

[36] Sikdar, R., Ganguly, U., Pal, P., Mazumder, B. and Sen, P.C. (1991) Biochemical characterizationof a calcium ion
stimulated-ATPase from goat spermatozoa. Molecular and Cellular Biochemistry, 103, 121-130. doi:10.1007/BF00227478

[37] Bhattacharyya, D. and Sen, P.C. (1998) Purification and functional characterization of a low-molecular-mass $\mathrm{Ca}^{2+}$, $\mathrm{Mg}^{2+}$ - a nd $\mathrm{Ca}^{2+}$-ATPase modulator protein from rat brain cytosol. Biochemical Journal, 330, 95-101.

[38] Sikdar, R., Roy, K., Mandal, A.K. and Sen, P.C. (1999) Phosphorylation and dephosphorylation of $\mathrm{Mg}^{2+}$-Independent $\mathrm{Ca}^{2+}$-ATPase from goat spermatozoa. Journal of Bioscience, 24, 317-321. doi:10.1007/BF02941245

[39] Sikdar, R., Ganguly, U., Chandra, S., Adhikary, G. and Sen, P.C. (1993) Calcium uptake and $\mathrm{Ca}^{2+}$-ATPase active ity in goat spermatozoa membrane vesicles do not require $\mathrm{Mg}^{2+}$. Journal of Bioscience, 18, 73-82. doi:10.1007/BF02703039

[40] Maeda, M., Ishizaki, J. and Futai, M. (1988) cDNA cloning and sequence determination of pig gastric $\mathrm{H}^{+}+\mathrm{K}^{+}$ATPase. Biochemical and Biophysical Research Commununication, 157, 203-209.

[41] Crowson, M.S. and Shull, G.E. (1992) Isolation and characterization of a cDNA encoding the putative distal colon $\mathrm{H}^{+}, \mathrm{K}^{+}$-ATPase. Similarity of deduced amino acid sequence to gastric $\mathrm{H}^{+}, \mathrm{K}^{+}$-ATPase and $\mathrm{Na}^{+}, \mathrm{K}^{+}$-ATPase and mRNA expression in distal colon, kidney, and uterus. Journal of Biological Chemistry, 267, 13740-13748.

[42] Jaisser, F., Horisberger, J.D., Geering, K. and Rossier, B.C. (1993) Mechanisms of urinary $\mathrm{K}^{+}$and $\mathrm{H}^{+}$excretion: primary structure and functional expression of a novel $\mathrm{H}^{+}$, $\mathrm{K}^{+}$-ATPase. Journal of Cell Biology, 123, 1421-1429. doi:10.1083/jcb.123.6.1421

[43] Yao, X. and Forte, J.G. (2003) Cell biology of acid secretion by the parietal cell. Annual Review of Physiology, 65, 1103-1131.

[44] Garty, H. and Karlish, S.J. (2006) Role of FXYD proteins in ion transport. Annual Review of Physiology, 68, 431-459. doi:10.1146/annurev.physiol.68.040104.131852

[45] Sen, P.C. (2001) Ion transporting enzymes and their regulation by endogenous modulators. Proceedings of the National Academy of Sciences, India, 71, 83-102.

[46] Skou, J.C. (1957) The influence of some cations on an adenosine triphosphatase from peripheral nerves. Biochimica et Biophysica Acta, 23, 394-401. doi:10.1016/0006-3002(57)90343-8

[47] Schwartz, A., Lindenmayer, G.E. and Allen, J.C. (1975) The sodium-potassium adenosine triphosphatase: Pharmacological, physiological and biochemical aspects. Pharmacological Review, 27, 3-134.

[48] Hasselbach, W. and Makinose, M. (1961) The calcium pump of the "relaxing granules" of muscle and its dependence on ATP-splitting. Biochemical Journal, 333, 518-528.

[49] Alberts, R.W. (1967) Biochemical aspects of active transport. Annual Review of Biochemistry, 36, 727-756. doi:10.1146/annurev.bi.36.070167.003455

[50] Monteith, G.R. and Roufogalis, B.D. (1995) The plasma membrane calcium pump-a physiological perspective on its regulation. Cell Calcium, 18, 459-470. doi:10.1016/0143-4160(95)90009-8

[51] Penniston, J.T. and Enyedi, A. (1998) Modulation of the plasma membrane $\mathrm{Ca}^{2+}$ pump. Journal of Membrane Biology, 165, 101-109. doi:10.1007/s002329900424 
[52] Guerini, D. (1998) The significance of the isoforms of plasma membrane calcium ATPase. Cell and Tissue Research, 292, 191-197. doi:10.1007/s004410051050

[53] Carafoli, E. (1991) Calcium pump of the plasma membrane. Physiological Review, 71, 129-153.

[54] Strehler, E.E., Filoteo, A.G., Penniston, J.T. and Caride, A.J. (2007) Plasma-membrane $\mathrm{Ca}^{2+}$ pumps: Structural diversity as the basis for functional versatility. Biochemical Society Transactions, 35, 919-922. doi:10.1042/BST0350919

[55] Moller, J.V., Juul, B. and le Maire, M. (1996) Structural organization, ion transport, and energy transduction of Ptype ATPases. Biochimica et Biophysica Acta, 1286, 151.

[56] Sorensen, T.L., Clausen, J.D., Jensen, A.M., Vilsen, B., Moller, J.V., Andersen, J.P. and Nissen, P. (2004) Localization of a $\mathrm{K}^{+}$-binding site involved in dephosphorylation of the sarcoplasmic reticulum $\mathrm{Ca}^{2+}$-ATPase. Journal of Biological Chemistry, 279, 46355-46358. doi:10.1074/jbc.C400414200

[57] Olesen, C., Sorensen, T.L., Nielsen, R.C., Moller, J.V. and Nissen, P. (2004). Dephosphorylation of the calcium pump coupled to counterion occlusion. Science, 306, 2251-2255. doi:10.1126/science. 1106289

[58] Olesen, C., Picard, M., Winther, A.M., Gyrup, C., Morth, J.P., Oxvig, C., Moller, J.V. and Nissen, P. (2007) The structural basis of calcium transport by the calcium pump. Nature, 450, 1036-1042. doi:10.1038/nature06418

[59] Jensen, A.M., Sorensen, T.L., Olesen, C., Moller, J.V. and Nissen, P. (2006) Modulatory and catalytic modes of ATP binding by the calcium pump. EMBO Journal, 25, 2305-2314. doi:10.1038/sj.emboj.7601135

[60] Clausenm, J.D., McIntosh, D.B., Vilsen, B., Woolley, D.G. and Andersen, J.P. (2003) Importance of conserved N- domain residues Thr441, Glu442, Lys515, Arg560, and Leu562 of sarcoplasmic reticulum $\mathrm{Ca}^{2+}$-ATPase for $\mathrm{Mg}$-ATP binding and subsequent catalytic steps. Plasticity of the nucleotide-binding site. Journal of Biological Chemistry, 278, 20245-20258. doi:10.1074/jbc.M301122200

[61] McIntosh, D.B., Clausen, J.D., Woolley, D.G., MacLennan, D.H., Vilsen, B. and Andersen, J.P. (2003) ATP binding residues of sarcoplasmic reticulum $\mathrm{Ca}^{2+}$-ATPase. Annual New York Academy of Sciences, 986, 101-105. doi:10.1111/j.1749-6632.2003.tb07145.x

[62] Rice, W.J., Young, H.S., Martin, D.W., Sachs, J.R. and Stokes, D.L. (2001) Structure of $\mathrm{Na}^{+}, \mathrm{K}^{+}$-ATPase at 11-A resolution: comparison with $\mathrm{Ca}^{2+}$-ATPase in $\mathrm{E}_{1}$ and $\mathrm{E}_{2}$ states. Biophysical Journal, 80, 2187-2197. doi:10.1016/S0006-3495(01)76191-7

[63] edemont, C.H. and Bertorello, A.M. (2001) Short-term regulation of the proximal tubule $\mathrm{Na}+, \mathrm{K}+$-ATPase: Increased/decreased $\mathrm{Na}^{+}, \mathrm{K}^{+}$-ATPase activity mediated by protein kinase $\mathrm{C}$ isoforms. Journal of Bioenergetics and Biomembranes, 33, 439-444.

[64] Morth, J.P., Pedersen, B.P., Toustrup-Jensen, M.S., Sorensen, T.L., Petersen, J., Andersen, J.P., Vilsen, B. and Nissen, P. (2007) Crystal structure of the sodiumpotassium pump. Nature, 450, 1043-1049. doi:10.1038/nature06419

[65] Morth, J.P., Poulsen, H., Toustrup-Jensen, M.S., Schack,
V.R., Egebjerg, J., Andersen, J.P., Vilsen, B. and Nissen, P. (2009) The structure of the $\mathrm{Na}^{+}, \mathrm{K}^{+}$-ATPase and mapping of isoform differences and disease-related mutations. Philosohical Transactions of the Royal Society, London, Biological Science, 364, 217-227.

doi:10.1098/rstb.2008.0201

[66] Shinoda, T., Ogawa, H., Cornelius, F. and Toyoshima, C. (2009) Crystal structure of the sodium-potassium pump at 2.4 A resolution. Nature, 459, 446-450. doi:10.1038/nature07939

[67] Jorgensen, P.L., Hakansson, K.O. and Karlish, S.J. (2003) Structure and mechanism of $\mathrm{Na}^{+}, \mathrm{K}^{+}$-ATPase: Functional sites and their interactions. Annual Review of Physiology, 65, 817-849. doi:10.1146/annurev.physiol.65.092101.142558

[68] Daih, T., Yamasaki, K., Danko, S. and Suzuki, H. (2007) Critical role of Glu40-Ser48 loop linking actuator domain and first transmembrane helix of Ca2+-ATPase in $\mathrm{Ca}^{2+}$ deocclusion and release from ADP-insensitive phosphoenzyme. Journal of Biological Chemistry, 282, 3442934447. doi:10.1074/jbc.M707665200

[69] Clausen, J.D., Vilsen, B., McIntosh, D.B., Einholm, A.P. and Andersen, J.P. (2004) Glutamate-183 in the conserved TGES motif of domain A of sarcoplasmic reticulum $\mathrm{Ca}^{2+}$-ATPase assists in catalysis of E2/E2P partial reactions. Proceedings of the National Academy of Sciences of the USA, 101, 2776-2781.

[70] Takeuchi, A., Reyes, N., Artigas, P. and Gadsby, D.C. (2008) The ion pathway through the opened $\mathrm{Na}^{+}, \mathrm{K}^{+}$ATPase pump. Nature, 456, 413-416. doi:10.1038/nature 07350

[71] Inesi, G., Ma, H., Lewis, D. and Xu, C. (2004) $\mathrm{Ca}^{2+}$ occlusion and gating function of Glu309 in the ADP-fluoroaluminate analog of the $\mathrm{Ca}^{2+}$-ATPase phosphoenzyme intermediate. Journal of Biological Chemistry, 279, 31629-31637. doi:10.1074/jbc.M403211200

[72] Pedersen, B.P., Buch-Pedersen, M.J., Morth, .J.P, Palmgren, M.G. and Nissen, P. (2007) Crystal structure of the plasma membrane proton pump. Nature, 450, 1111-1114. doi:10.1038/nature06417

[73] Sorensen, T.L., Moller, J.V. and Nissen, P. (2004) Phosphoryl transfer and calcium ion occlusion in the calcium pump. Science, 304, 1672-1675. doi:10.1126/science.1099366

[74] Toyoshima, C., Norimatsu, Y., Iwasawa, S., Tsuda, T. and Ogawa, H. (2007) How processing of aspartylphosphate is coupled to lumenal gating of the ion pathway in the calcium pump. Proceedings of the National Academy of Sciences of the USA, 104, 19831-19836. doi:10.1073/pnas.0709978104

[75] Ogawa, H., Shinoda, T., Cornelius, F. and Toyoshima, C. (2009) Crystal structure of the sodium-potassium pump $\mathrm{Na}^{+}, \mathrm{K}^{+}$-ATPase with bound potassium and ouabain. Proceedings of the National Academy of Sciences of the USA, 106, 13742-13747.

[76] Toustrup-Jensen, M.S., Holm, R., Einholm, A.P., Schack, V.R., Morth, J.P., Nissen, P., Andersen, J.P. and Vilsen, B. (2009) The $\mathrm{C}$ terminus of $\mathrm{Na}^{+}, \mathrm{K}^{+}$-ATPase controls $\mathrm{Na}^{+}$ affinity on both sides of the membrane through Arg-935. Journal of Biological Chemistry, 284, 18715-18725. doi:10.1074/jbc.M109.015099 
[77] Tavraz, N.N., Friedrich, T., Durr, K.L., Koenderink, J.B., Bamberg, E., Freilinger, T. and Dichgans, M. (2008) Diverse functional consequences of mutations in the $\mathrm{Na}^{+} /$ $\mathrm{K}^{+}$-ATPase alpha2-subunit causing familial hemiplegic migraine type 2. Journal of Biological Chemistry, 283, 31097-31106. doi:10.1074/jbc.M802771200

[78] Yaragatupalli, S., Olivera, J.F., Gatto, C. and Artigas, P. (2009) Altered $\mathrm{Na}^{+}$transport after an intracellular alpha-subunit deletion reveals strict external sequential release of $\mathrm{Na}^{+}$from the $\mathrm{Na} / \mathrm{K}$ pump. Proceedings of the National Academy of Sciences of the USA, 106, 1550715512. doi:10.1073/pnas.0903752106

[79] Poulsen, H., Khandelia, H., Morth, J.P., Bublitz, M., Mouritsen, O.G., Egebjerg, J. and Nissen, P. (2010) Neurological disease mutations compromise a C-termnal ion pathway in the $\mathrm{Na}^{+}, \mathrm{K}^{+}$-ATPase. Nature, 467, 99-102. doi:10.1038/nature09309

[80] Morth, J.P., Pedersen, B.P., Buch-Pedersen, M.J., Andersen, J.P., Vilsen, B., Palmgren, M.G. and Nissen P (2011) A structural overview of the plasma membrane $\mathrm{Na}^{+}, \mathrm{K}^{+}$-ATPase and $\mathrm{H}^{+}$-ATPase ion pumps. Nature Review Molecular Cellular Biology, 12, 60-70.

[81] Toyoshima, C. (2009) How $\mathrm{Ca}^{2+}$-ATPase pumps ions across the sarcoplasmic reticulum membrane. Biochimica et Biophysica Acta, 1793, 941-946. doi:10.1016/j.bbamcr.2008.10.008

[82] Hernandez, R.J. (1992) $\mathrm{Na}^{+}, \mathrm{K}^{+}$-ATPase regulation by neurotransmitters. Neurochemistry International, 20, 1-10. doi:10.1016/0197-0186(92)90119-C

[83] Raynor, R.L., Zheng, B. and Kuo, J.F. (1991) Membrane interactions of amphiphilic polypeptides mastoparan, melittin, polymyxin B, and cardiotoxin. Differential inhibition of protein kinase $\mathrm{C}, \mathrm{Ca}^{2+}$ /calmodulin-dependent protein kinase II and synaptosomal membrane $\mathrm{Na}^{+}, \mathrm{K}^{+}$-ATPase, and $\mathrm{Na}^{+}$pump and differentiation of HL60 cells. Journal of Biological Chemistry, 266, 2753-2758.

[84] Zeidel, M.L., Brady, H.R., Kone, B.C., Gullans, S.R. and Brenner, B.M. (1989) Endothelin, a peptide inhibitor of $\mathrm{Na}^{+}-\mathrm{K}^{+}$-ATPase in intact renaltubular epithelial cells. American Journal of Physiology, 257, C1101-C1107.

[85] Chih-Fang, C., Shean-Tai, C., Hellen, J. and Wen-Chang, C. (1996) The porcine sperm motility inhibitor is identical to b-microseminoprotein and is a competitive inhibitor of $\mathrm{Na}^{+}, \mathrm{K}^{+}$-ATPase. Biochemical Biophysical Research Communication, 218, 623-628.

[86] Goto, A., Yamada, K., Yagi, N., Yoshioka, M. and Sugimoto, T. (1992) Physiology and pharmacology of endogenous digitalis-like factors. Pharmacological Review, 44, 377-399.

[87] Fehlmann, M. and Freychet, P. (1981) Insulin and glucagon stimulation of $\mathrm{Na}^{+}-\mathrm{K}^{+}$-ATPase transport activity in isolated rat hepatocytes. Journal of Biological Chemistry, 256, 7449-7453.

[88] Olivera, W.G., Ciccolella, D.E., Barquin, N., Ridge, K.M., Rutschman, D.H., Yeates, D.B. and Sznajder, J. (2000) Aldosterone regulates $\mathrm{Na}^{+}, \mathrm{K}^{+}$-ATPase and increases lung edema clearance in rats. American Journal of Respiration and Critical Care Medicine, 161, 567-573.

[89] Krishnamoorthy, R.R., Prasanna, G., Dauphin, R., Hulet, C., Agarwal, N. and Yorio, T. (2003) Regulation of $\mathrm{Na}^{+}$, $\mathrm{K}^{+}$-ATPase expression by endothelin-1 in transformed hu- man ciliary non-pigmented epithelial (HNPE) cells. Journal of Ocular Pharmacology and Therapeutics, 19, 465481. doi:10.1089/108076803322473024

[90] Elkouby, A., Ledig, M. and Mandel, P. (1982) Effect of hydrocortisone and thyroxine on ATPase activities of neuronal and glial cell lines in culture. Neurochemistry Research, 7, 387-397. doi:10.1007/BF00965492

[91] Brazy, P.C., Trellis, D.R. and Klotman, P.E. (1985) Bradykinin stimulation of oxidative metabolism in renal cortical tubules from rabbit. Possible role of arachidonic acid. Journal of Clinical Investigation, 76, 1812-1818. doi:10.1172/JCI112173

[92] Wojtkowiak, R., Turska, E., Lachowicz, L. and Koziolkiewicz, W. (1990) Effects of N- and C-terminal fragments of substance $\mathrm{P}$ on ATPase and monoamine oxidase activeties in rat brain. General Pharmacology, 21, 403-406. doi:10.1016/0306-3623(90)90688-I

[93] Crambert, G., Fuzesi, M., Garty, H., Karlish, S. and Geering, K. (2002) Phospholemman (FXYD1) associates with $\mathrm{Na}, \mathrm{K}-\mathrm{ATPase}$ and regulates its transport properties. Proceedings of the National Academy of Sciences of the USA, 99, 11476-11481.

[94] Arystarkhova, E., Wetzel, R.K., Asinovski, N.K. and Sweadner, K.J. (1999) The gamma subunit modulates $\mathrm{Na}^{+}$ and $\mathrm{K}^{+}$affinity of the renal $\mathrm{Na}^{+}, \mathrm{K}^{+}$-ATPase. Journal of Biological Chemistry, 274, 33183-33185. doi:10.1074/jbc. 274.47 .33183

[95] Therien, A.G., Karlish, S.J. and Blostein, R. (1999) Expression and functional role of the gamma subunit of the $\mathrm{Na}^{+}, \mathrm{K}^{+}$-ATPase in mammalian cells. Journal of Biological Chemistry, 274, 12252-12256. doi:10.1074/jbc.274.18.12252

[96] Crambert, G., Li, C., Claeys, D. and Geering, K. (2005) FXYD3 (Mat-8), a new regulator of $\mathrm{Na}^{+}, \mathrm{K}^{+}$-ATPase. $M o$ lecular Biology of Cell, 16, 2363-2371. doi:10.1091/mbc.E04-10-0878

[97] Beguin, P., Crambert, G., Guennoun, S., Garty, H., Horisberger, J.D. and Geering, K. (2001) CHIF, a member of the FXYD protein family, is a regulator of $\mathrm{Na}^{+}, \mathrm{K}^{+}$-ATPase distinct from the gamma-subunit. EMBO Journal, 20, 3993-4002. doi:10.1093/emboj/20.15.3993

[98] Garty, H., Lindzen, M., Scanzano, R., Aizman, R., Fuzesi, M., Goldshleger, R., Farman, N., Blostein, R . and Karlish, S.J. (2002) A functional interaction between CHIF and $\mathrm{Na}^{+}-\mathrm{K}^{+}$-ATPase: implication for regulation by FXYD proteins. American Journal of Physiology, Renal Physiology, 283, F607-F615.

[99] Ino, Y., Gotoh, M., Sakamoto, M., Tsukagoshi, K. and Hirohashi, S. (2002) Dysadherin, a cancer-associated cell membrane glycoprotein, down-regulates E-cadherin and promotes metastasis. Proceedings of the National Academy of Sciences, USA, 99, 365-670. doi:10.1073/pnas.012425299

[100] Beguin, P., Crambert, G., Monnet-Tschudi, F., Uldry, M., Horisberger, J.D., Garty, H. and Geering, K. (2002) FXYD7 is a brain-specific regulator of $\mathrm{Na}^{+}, \mathrm{K}^{+}$-ATPase alpha 1-beta isozymes. EMBO Journal, 21, 3264-3273. doi:10.1093/emboj/cdf330

[101] Delprat, B., Schaer, D., Roy, S., Wang, J., Puel, J.L. and Geering, K. (2007) FXYD6 is a novel regulator of $\mathrm{Na}^{+}, \mathrm{K}^{+}$ -ATPase expressed in the inner ear. Journal of Biological Chemistry, 282, 7450-7456. doi:10.1074/jbc.M609872200 
[102] Cornelius, F. and Mahmmoud, Y.A. (2003) Direct activetion of gastric $\mathrm{H}^{+}, \mathrm{K}^{+}$-ATPase by $\mathrm{N}$-terminal protein kinase $\mathrm{C}$ phosphorylation. Comparison of the acute regulation mechanisms of $\mathrm{H}^{+}, \mathrm{K}^{+}$-ATPase and $\mathrm{Na}^{+}, \mathrm{K}^{+}$-ATPase. Biophysical Journal, 84, 1690-1700. doi:10.1016/S0006-3495(03)74977-7

[103] Kairane, C., Zilmer, M., Mutt, V. and Sillard, R. (1994) Activation of $\mathrm{Na}^{+}, \mathrm{K}^{+}$-ATPase by an endogenous peptide, PEC-60. FEBS Letters, 345, 1-4. doi:10.1016/0014-5793(94)00407-2

[104] De Lores-Arnaiz, G.R., de Lima, M.M.A.D.G. and Girardi, E. (1988) Different properties of two brain extracts separated sephadex G50 that modify synaptosomal activeties, Neurochemistry Research, 13, 229-235. doi:10.1007/BF00971538

[105] Bhattacharyya, D. and Sen, P.C. (1997) Purification and functional characterization of a low-molecular-mass $\mathrm{Na}^{+}$, $\mathrm{K}^{+}$-ATPase inhibitor protein from rat brain cytosol. European Journal of Biochemistry, 244, 829-834. doi:10.1111/j.1432-1033.1997.00829.x

[106] Mandal, A.K., Roy, K., Sil, P.C., Yadav, S.P. and Sen, P.C. (2001) Purification, characterization and partial amino acid sequencing of a $70 \mathrm{kD}$ inhibitor protein of $\mathrm{Na}^{+}, \mathrm{K}^{+}$-ATPase from goat testis cytosol. Molecular and Cellular Biochemistry, 223, 7-14. doi:10.1023/A:1017527026796

[107] Roy, K., Mandal, A.K. and Sen, P.C. (1999) A 75-kDa Na ${ }^{+}$, $\mathrm{K}^{+}$-ATPase competitive inhibitor protein isolated from rat brain cytosol binds to a site different from the ouabainbinding site. European Journal of Biochemistry, 261, 84-88. doi:10.1046/j.1432-1327.1999.00212.x

[108] Dhara, T.K., Chatterjee, M., Bera, R. and Sen, P.C. (2009) Characterization of arylsulphatase $\mathrm{A}$ in a $70 \mathrm{kDa}$ protein isolated from goat spermatozoa having $\mathrm{Na}^{+}, \mathrm{K}^{+}$-ATPase inhibitory activity. Indian Journal of Biochemistry and Biophysics, 40, 230-236.

[109] Tantibhedhyangkul, J., Weerachatyanukul, W., Carmona, E., Xu, H., Anupriwan, A., Michaud, D. and Tanphaichitr, N. (2002) Role of sperm surface arylsulfatase A in mouse sperm-zona pellucida binding. Biology of Reproduction, 67, 212-219. doi:10.1095/biolreprod67.1.212

[110] Carmona, E., Weerachatyanukul, W., Soboloff, T., Fluharty, A.L., White, D., Promdee, L., Ekker, M., Berger, T., Buhr, M. and Tanphaichitr, N. (2002) Arylsulfatase a is present on the pig sperm surface and is involved in sperm-zona pellucida binding. Developmental Biology, 247, 182-196. doi:10.1006/dbio.2002.0690

[111] Kreysing, J., Polten, A., Lukatela, G., Matzner, U., von Figura, K. and Gieselmann, V. (1994) Translational control of arylsulfatase A expression in mouse testis. Journal of Biological Chemistry, 269, 23255-23261.

[112] Mao, H., Ferguson, T.S., Cibulsky, S.M., Holmqvist, M., Ding, C., Fei, H. and Levitan, I.B. (2005) MONaKA, a novel modulator of the plasma membrane $\mathrm{Na}^{+}, \mathrm{K}^{+}$-ATPase. Journal of Neuroscience, 25, 7934-7943. doi:10.1523/JNEUROSCI.0635-05.2005

[113] Tamura, M., Harris, T.M., Konishi, F. and Inagami, T. (1993) Isolation and characterization of an endogenous $\mathrm{Na}^{+}, \mathrm{K}^{+}$-ATPase-specific inhibitor from pig urine. European Journal of Biochemistry, 211, 317-327. doi:10.1111/j.1432-1033.1993.tb19901.x

[114] Araki, K., Kuroki, J., Ito, O., Kuwada, M. and Tachibana, S. (1989) Novel peptide inhibitor (SPAI) of $\mathrm{Na}^{+}, \mathrm{K}^{+}$-AT-
Pase from porcine intestine. Biochemical Biophysical Research Communication, 164, 496-502.

[115] Halperin, J.A. (1989) Digitalis-like properties of an inhibitor of the $\mathrm{Na}^{+} / \mathrm{K}^{+}$pump in human cerebrospinal fluid. Journal of Neurological Science, 90, 217-230. doi:10.1016/0022-510X(89)90103-2

[116] Therien, A.G. and Blostein, R. (2000) Mechanisms of sodium pump regulation. American Journal of Physiology, Cell Physiology, 279, C541-C566.

[117] Sweadner, K.J. and Feschenko, M.S. (2001) Predicted location and limited accessibility of protein kinase A phosphorylation site on $\mathrm{Na}^{+}, \mathrm{K}^{+}$-ATPase. American Journal of Physiology, Cell Physiology, 280, C1017-C1026.

[118] Mauldin, D. and Roufogalis, B.D. (1980) A protein activator of $\mathrm{Mg}^{2+}$-dependent, $\mathrm{Ca}^{2+}$-stimulated ATPase in human erythrocyte membranes distinct from calmodulin. Biochemical Journal, 187, 507-513.

[119] Yamaguchi, M. and Nakajima, R. (2002) Role of regucalcin as an activator of sarcoplasmic reticulum $\mathrm{Ca}^{2+}$ ATPase activity in rat heart muscle. Journal of Cellular Biochemistry, 86, 184-193. doi:10.1002/jcb.10209

[120] Niggli, V., Adunyah, E.S. and Carafoli, E. (1981) Acidic phospholipids, unsaturated fatty acids, and limited proteolysis mimic the effect of calmodulin on the purified erythrocyte $\mathrm{Ca}^{2+}$-ATPase. Journal of Biological Chemistry, 256, 8588-8592.

[121] Minocherhomjee, A.V. and Roufogalis, B.D. (1982) Activation of erythrocyte $\mathrm{Ca}^{2+}$-plus- $\mathrm{Mg}^{2+}$-stimulated adenosine triphosphatase by protein kinase (cyclic AMP-dependent) inhibitor. Comparison with calmodulin. Biochemical Journal, 206, 517-525.

[122] Sengupta, T., Ghoshal, S. and Sen, P.C. (2007) Stimulation of $\mathrm{Mg}^{2+}$-independent form of $\mathrm{Ca}^{2+}$-ATPase by a low molecular mass protein purified from goat testes cytosol. Comparative Biochemistry and Physiology B, Biochemistry and Molecular Biology, 146, 131-138.

[123] Sengupta, T., Ghoshal, S., Dungdung, S.R., Majumder, G.C. and Sen, P.C. (2008) Structural and functional characterization and physiological significance of a stimulator protein of $\mathrm{Mg}^{2+}$-indep endent $\mathrm{Ca}^{2+}$-ATPase isolated from goat spermatozoa. Molecular and Cellular Biochemistry, 311, 93-103. doi:10.1007/s11010-007-9700-6

[124] Ghoshal, S., Sengupta, T. and Sen, P.C. (2006) Regulation of $\mathrm{Mg}^{2+}$-independent $\mathrm{Ca}^{2+}$-ATPase by a low molecular mass protein purified from bovine brain. Biofactors, 26, 259-271. doi:10.1002/biof.5520260404

[125] Ghoshal, S., Sengupta, T., Dundung, S.R., Majumder, G.C. and Sen, P.C. (2008) Characterization of a low-molecular-mass stimulator protein of $\mathrm{Mg}^{2+}$-independent $\mathrm{Ca}^{2+}$ ATPase: Effect on phosphorylation/dephosphorylation, calcium transport and sperm-cell motility. Bioscience Report, 28, 61-71. doi:10.1042/BSR20070016

[126] Narayanan, N., Lee, P., Newland, M. and Khandelwal, R.L. (1982) Evidence for an endogenous protein inhibitor of sarcoplasmic reticulum Ca-ATPase in heart muscle. Biochemical Biophysical Research Communication, 108, 1158-1164. doi:10.1016/0006-291X(82)92122-2

[127] Javed, M.U., Naru, T. and Michelangeli, F. (2000) An endogenous inhibitor of $\mathrm{Ca}^{2+}$-ATPase from human placenta. Journal of Enzyme Inhibitor, 15, 163-170. doi:10.1080/14756360009030348

[128] Asahi, M., Sugita, Y., Kurzydlowski, K., De Leon, S., 
Tada, M., Toyoshima, C. and MacLennan, D.H. (2003) Sarcolipin regulates sarco(endo)plasmic reticulum $\mathrm{Ca}^{2+}$ ATPase (SERCA) by binding to transmembrane helices alone or in association with phospholamban. Proceedings of the National Academy of Sciences of the USA, 100, 5040-5045. doi:10.1073/pnas.0330962100

[129] Kim, H.W., Steenaart, N.A., Ferguson, D.G. and Kranias, E.G. (1990) Functional reconstitution of the cardiac sarcoplasmic reticulum $\mathrm{Ca}^{2+}$-ATPase with phospholamban in phospholipid vesicles. Journal of Biological Chemistry, 265, 1702-1709.

[130] Simmerman, H.K., Collins, J.H., Theibert, J.L., Wegener, A.D. and Jones, L.R. (1986) Sequence analysis of phospholamban. Identification of ph osphorylation sites and two major structural domains. Journal of Biological Chemistry, 261, 13333-13341.

[131] Haghighi, K., Gregory, K.N. and Kranias, E.G. (2004) Sarcoplasmic reticulum $\mathrm{Ca}^{2+}$-ATPase-phosphor-lamban interactions and dilated cardiomyopathy. Biochemical Biophysical Research Communication, 322, 1214-1222. doi:10.1016/j.bbrc.2004.07.164

[132] Kimura, Y., Asahi, M., Kurzydlowski, K., Tada, M. and MacLennan, D.H. (1998) Phospholamban domain $\mathrm{Ib}$ mutations influence functional interactions with the $\mathrm{Ca}^{2+}$ ATPase isoform of cardiac sarcoplasmic reticulum. Journal of Biological Chemistry, 273, 14238-14241. doi:10.1074/jbc.273.23.14238

[133] Haghighi, K., Kolokathis,, F., Pater, L., Lynch, R.A., Asahi, M.A.O., Gramolini, G.C., Fan, D., Tsiapras, H.S., Hahn, S., Adamopoulos, S.B., Liggett, G.W., Dorn Jr., D.H., MacLennan, D.H., Kremastinos, D.T. and Kranias, E.G. (2003) Human phospholamban null results in lethal dilated cardiomyopathy revealing a critical difference between mouse and human. Journal of Clinical Investigation, 111, 869-876.

[134] Chaudhary, J., Walia, M., Matharu, J., Escher, E. and Grover, A.K. (2001) Caloxin: A novel plasma membrane $\mathrm{Ca}^{2+}$ pump inhibitor. American Journal of Physiology, Cell Physiology, 280, C1027-C1030.

[135] Pande, J., Mallhi, K.K. and Grover, A.K. (2005) A novel plasma membrane $\mathrm{Ca}^{2+}$-pump inhibitor: caloxin 1A1. European Journal of Pharmacology, 508, 1-6. doi:10.1016/j.ejphar.2004.11.057

[136] Cao, C.M., Xia, Q., Bruce, I.C., Zhang, X., Fu, C. and Chen, J.Z. (2003) Interleukin-2 increases activity of sarcoplasmic reticulum $\mathrm{Ca}^{2+}$-ATPase, but decreases its sensitivity to calcium in rat cardiomyocytes. Journal of Pharmacology and Experimental Therapeutics, 306, 572580. doi:10.1124/jpet.102.048264

[137] Segal, J., Hardiman, J. and Ingbar, S.H. (1989) Stimulation of calcium-ATPase activity by 3,5,3'-tri-iodothy-ronine in rat thymocyte plasma membranes. A possible role in the modulation of cellular calcium concentration. Biochemical Journal, 261, 749-754.

[138] Longland, C.L., Mezna, M. and Michelangeli, F. (1999) The mechanism of inhibition of the $\mathrm{Ca}^{2+}$-ATPase by mastoparan. Mastoparan abolishes cooperative $\mathrm{Ca}^{2+}$ binding. Journal of Biological Chemistry, 274, 14799-147805. doi:10.1074/jbc.274.21.14799

[139] Baker, K.J., East, J.M. and Lee, A.G. (1995) Mechanism of inhibition of $\mathrm{Ca}^{2+}$-ATPase by myotoxin a. Biochemical
Journal, 307, 571-579.

[140] Voss, J., Birmachu, W., Hussey, D.M. and Thomas, D.D. (1991) Effects of melittin on molecular dynamics and $\mathrm{Ca}^{2+}$-ATPase activity in sarcoplasmic reticulum membranes: Time-resolved optical anisotropy. Biochemistry, 30, 7498-7506. doi:10.1021/bi00244a019

[141] Kockskamper, J., Ahmmed, G.U., Zima, A.V., Sheehan, K.A., Glitsch, H.G. and Blatter, L.A. (2004) Palytoxin disrupts cardiac excitation-contraction coupling through interactions with P-type ion pumps. American Journal of Physiology, Cell Physiology, 287, C527-C538. doi:10.1152/ajpcell.00541.2003

[142] Hughes, G., Starling, A.P., East, J.M. and Lee, A.G. (1994) Mechanism of inhibition of the $\mathrm{Ca}^{2+}$-ATPase by spermine and other polycationic compounds. Biochemistry, 33, 4745-4754. doi:10.1021/bi00182a001

[143] Starling, A.P., Hughes, G., East, J.M. and Lee, A.G. (1994) Mechanism of stimulation of the calcium adenosinetriphosphatase by jasmone. Biochemistry, 33, 3023- 3031. doi:10.1021/bi00176a035

[144] Colina, C., Cervino, V. and Benaim, G. (2002) Ceramide and sphingosine have an antagonistic effect on the plasma-membrane $\mathrm{Ca}^{2+}$-ATPase from human erythrocytes. Biochemical Journal, 362, 247-251. doi:10.1042/0264-6021:3620247

[145] Bilmen, J.G., Wootton, L.L. and Michelangeli, F. (2002) The inhibition of the sarcoplasmic/endoplasmic reticulum $\mathrm{Ca}^{2+}$-ATPase by macrocyclic lactones and cyclosporin A. Biochemical Journal, 366, 255-263.

[146] Ishizuka, N., Fukushima, Y., Urayama, O. and Akera, T. (1991) $\mathrm{Na}^{+}, \mathrm{K}^{+}$-ATPase inhibition by an endogenous peptide, SPAI-1, isolated from porcine duodenum. Biochimica et Biophysica Acta, 1069, 259-266. doi:10.1016/0005-2736(91)90133-S

[147] Li, C., Grosdidier, A., Crambert, G., Horisberger, J.D., Michielin, O. and Geering, K. (2004) Structural and functional interaction sites between $\mathrm{Na}^{+}, \mathrm{K}^{+}$-ATPase and FXYD proteins. Journal of Biological Chemistry, 279, 38895-38902. doi:10.1074/jbc.M406697200

[148] Geering, K. (2008). Functional roles of $\mathrm{Na}^{+}, \mathrm{K}^{+}$-ATPase subunits. Current Opinion of Nephrology and Hypertension, 17, 526-532. doi:10.1097/MNH.0b013e3283036cbf

[149] Teriete, P., Thai, K., Choi, J. and Marassi, F.M. (2009) Effects of PKA phosphorylation on the conformation of the $\mathrm{Na}^{+}, \mathrm{K}^{+}$-ATPase regulatory protein FXYD1. Biochimica et Biophysica Acta, 1788, 2462-2470. doi:10.1016/j.bbamem.2009.09.001

[150] Okudela, K., Yazawa, T., Ishii, J., Woo, T., Mitsui, H., Bunai, T., Sakaeda, M., Shimoyamada, H., Sato, H., Tajiri, M., Ogawa, N., Masuda, M., Sugimura, H. and Kitamura, H. (2009) Down-regulation of FXYD3 expression in human lung cancers: Its mechanism and potential role in carcinogenesis. American Journal of Pathology, 175, 2646-2656. doi:10.2353/ajpath.2009.080571

[151] Saito, K., Nakamura, N., Ito, Y., Hoshijima, K., Esaki, M., Zhao, B. and Hirosa, S. (2010) Identification of zebrafish Fxyd11a protein that is highly expressed in ion-transporting epithelium of the gill and skin and its possible role in ion homeostasis. Frontier Physiology, 1, 129-138.

[152] Wang, P.J., Lin, C.H., Hwang, H.H. and Lee, T.H. (2008) Branchial FXYD protein expression in response to salinity change and its interaction with $\mathrm{Na}^{+}, \mathrm{K}^{+}$-ATPase of the 
euryhaline teleost Tetraodon nigroviridis. Journal of Experimental Biology, 211, 3750-3758. doi: $10.1242 /$ jeb. 018440

[153] Yudowski, G.A., Efendiev, R., Pedemonte, C.H., Katz, A.I., Berggren, P.O. and Bertorello, A.M. (2000) Phosphoinositide-3 kinase binds to a proline-rich motif in the $\mathrm{Na}^{+}, \mathrm{K}^{+}$-ATPase alpha subunit and regulates its trafficking. Proceedings of the National Academy of Sciences of the USA, 97, 6556-6561. doi:10.1073/pnas.100128297

[154] Haas, M.J., Li, J.P., Pun, K. and Mooradian, A.D. (2002) Partial characterization of a cerebral thyroid hormoneresponsive protein. Archives of Biochemistrynd Biophysics, 399, 6-11.

[155] Falchetto, R., Vorherr, T. and Carafoli, E. (1992) The calmodulin-binding site of the plasma membrane $\mathrm{Ca}^{2+}$ pump interacts with the transduction domain of the enzyme. Protein Science, 1, 1613-1621. doi:10.1002/pro.5560011209

[156] James, P., Maeda, M., Fischer, R., Verma, A.K., Krebs, J., Penniston, J.T. and Carafoli, E. (1988. Identification and primary structure of a calmodulin binding domain of the $\mathrm{Ca}^{2+}$ pump of human erythrocytes. Journal of Biological Chemistry, 263, 2905-2910.

[157] Holmes, M.E., Chaudhary, J. and Grover, A.K. (2003) Mechanism of action of the novel plasma membrane $\mathrm{Ca}^{2+}$-pump inhibitor caloxin. Cell Calcium, 5, 241-246. doi:10.1016/S0143-4160(02)00207-5

[158] Pande, J., Mallhi, K.K., Sawh, A., Szewczyk, M.M., Simpson, F. and Grover, A.K. (2006) Aortic smooth muscle and endothelial plasma membrane $\mathrm{Ca}^{2+}$ pump isoforms are inhibited differently by the extracellular inhibitor caloxin 1b1. American Journal of Physiology, Cell Physiology, 290, C1341-C1349. doi:10.1152/ajpcell.00573.2005

[159] Fuller, W., Eaton, P., Bell, J.R. and Shattock, M.J. (2004) Ischemia-induced phosphorylation of phospholemman directly activates rat cardiac $\mathrm{Na}^{+}, \mathrm{K}^{+}$-ATPase. Faseb Journal, 18, 197-199.

[160] Jia, L.G., Donnet, C., Bogaev, R.C., Blatt, R.J., McKinney, C.E., Day, K.H., Berr, S.S., Jones, L.R., Moorman, J.R., Sweadner, K.J. and Tucker, A.L. (2005) Hypertrophy, increased ejection fraction, and reduced $\mathrm{Na}^{+}, \mathrm{K}^{+}$ATPase activity in phospholemman-deficient mice. American Journal of Physiology, Heart and Circulation Physiology, 288, H1982-H1988.

[161] Bhupathy, P., Babu, G.J. and Periasamy, M. (2007) Sarcolipin and phospholamban as regulators of cardiac sarcoplasmic reticulum $\mathrm{Ca}^{2+}$-ATPase. Journal of Molecular and Cellular Cardiology, 42, 903-911. doi:10.1016/j.yjmcc.2007.03.738

[162] Uhlemann, A.C., Cameron, A., Eckstein-Ludwig, U., Fischbarg, J., Iserovich, P., Zuniga, F.A., East, M., Lee, A., Brady, L., Haynes, R.K. and Krishna, S. (2005) A single amino acid residue can determine the sensitivity of SERCAs to artemisinins. Nature Structural and Molecular Biology, 12, 628-629. doi:10.1038/nsmb947
[163] Lalli, J., Harrer, J.M., Luo, W., Kranias, E.G. and Paul, R.J. (1997) Targeted ablation of the phospholamban gene is associated with a marked decrease in sensitivity in aortic smooth muscle. Circulation Research, 80, 506-513.

[164] Kimura, Y., Asahi, M., Kurzydlowski, K., Tada, M. and MacLennan, D.H. (1998) Phospholamban domain I/cytochrome b5 transmembrane sequence chimeras do not inhibit SERCA2a. FEBS Letters, 425, 509-512. doi:10.1016/S0014-5793(98)00151-3

[165] Deborah, A., Ferrington, Q.Y., Thomas, C.S. and Bigelow, D.J. (2002) Comparable Levels of CaATPase Inhibition by Phospholamban in Slow-Twitch Skeletal and Cardiac Sarcoplasmic Reticulum. Biochemistry, 41, 1328913296. doi:10.1021/bi026407t

[166] Uemura, N., Ohkusa, T., Hamano, K., Nakagome, M., Hori, H., Shimizu, M., Matsuzaki, M., Mochizuki, S., Minamisawa, S. and Ishikawa, Y. (2004) Down-regulation of sarcolipin mRNA expression in chronic atrial fibrillation. European Journal of Clinical Investigation, 34, 723-730. doi:10.1111/j.1365-2362.2004.01422.x

[167] Odermatt, A., Taschner, P.E., Scherer, S.W., Beatty, B., Khanna, V.K., Cornblath, D.R., Chaudhry, V., Yee, W.C., Schrank, B., Karpati, G., Breuning, M.H., Knoers N. and MacLennan, D.H. (1997) Characterization of the gene encoding human sarcolipin (SLN), a proteolipid associated with SERCA1: absence of structural mutations in five patients with Brody disease. Genomics, 45, 541-553. doi:10.1006/geno.1997.4967

[168] Asahi, M., Nakayama, H., Tada, M. and Otsu, K. (2003) Regulation of sarco (endo)plasmic reticulum $\mathrm{Ca}^{2+}$ adenosine triphosphatase by phospholamban and sarcolipin: implication for cardiac hypertrophy and failure. Trends in Cardiovascular Medicine, 13, 152-157. doi:10.1016/S1050-1738(03)00037-9

[169] Mascioni, A., Karim, C., Barany, G., Thomas, D.D. and Veglia, G. (2002) Structure and orientation of sarcolipin in lipid environments. Biochemistry, 41, 475-482. doi:10.1021/bi011243m

[170] Buffy, J.J., Buck-Koehntop, B.A., Porcelli, F., Traaseth, N.J., Thomas, D.D. and Veglia, G. (2006) Defining the intramembrane binding mechanism of sarcolipin to calcium ATPase using solution NMR spectroscopy. Journal of Molecular Biology, 358, 420-429. doi:10.1016/j.jmb.2006.02.005

[171] Gramolini, A.O., Kislinger, T., Asahi, M., Li, W., Emili, A. and MacLennan, D.H. (2004) Sarcolipin retention in th e endoplasmic reticulum depends on its C-terminal RSYQY sequence and its interaction with sarco(endo)plasmic $\mathrm{Ca}^{2+}$ ATPases. Proceedings of the National Academy of Sciences of the USA, 101, 16807-16812. doi:10.1073/pnas.0407815101

[172] Morita, T., Hussain, D., Asahi, M., Tsuda, T., Kurzydlowski, K., Toyoshima, C. and Maclennan, D.H. (2008) Interaction sites among phospholamban, sarcolipin, and the sarco (endo) plasmic reticulum $\mathrm{Ca}^{2+}$-ATPase. Biochemical Biophysical Research Communication, 369, 188-194. doi:10.1016/j.bbrc.2007.11.098 